\title{
Biological Activities of Gedunin-A Limonoid from the Meliaceae Family
}

\author{
Teresa M. Braga ${ }^{1, * \mathbb{C}}$, Lídia Rocha ${ }^{1}{ }^{\mathbb{D}}$, Tsz Yan Chung ${ }^{1}$, Rita F. Oliveira ${ }^{1}$, Cláudia Pinho ${ }^{1}$, \\ Ana I. Oliveira ${ }^{1}$ D, Joaquim Morgado ${ }^{2,3}$ and Agostinho Cruz ${ }^{1, *}$ \\ 1 Centro de Investigação em Saúde e Ambiente, Escola Superior de Saúde, Instituto Politécnico do Porto, \\ 4200-072 Porto, Portugal; lcar@ess.ipp.pt (L.R.); tycg@ess.ipp.pt (T.Y.C.); rfo@ess.ipp.pt (R.F.O.); \\ clp@ess.ipp.pt (C.P.); aoliveira@ess.ipp.pt (A.I.O.) \\ 2 Bio4Life4You, 4460-170 Porto, Portugal; jcmorgado@bio4life4you.com \\ 3 World Neem Organization, Mumbai 400101, India \\ * Correspondence: tmfb@ess.ipp.pt (T.M.B.); agostinhocruz@ess.ipp.pt (A.C.)
}

Academic Editors: David Díez and María Ángeles Castro

Received: 20 December 2019; Accepted: 20 January 2020; Published: 23 January 2020

Abstract: Gedunin is an important limonoid present in several genera of the Meliaceae family, mainly in seeds. Several biological activities have been attributed to gedunin, including antibacterial, insecticidal, antimalarial, antiallergic, anti-inflammatory, anticancer, and neuroprotective effects. The discovery of gedunin as a heat shock protein ( $\mathrm{Hsp}$ ) inhibitor represented a very important landmark for its application as a biological therapeutic agent. The current study is a critical literature review based on the several biological activities so far described for gedunin, its therapeutic effect on some human diseases, and future directions of research for this natural compound.

Keywords: gedunin; limonoid; Meliaceae family; bioactive compound; biological activity

\section{Introduction}

The World Health Organization (WHO) estimates the existence of 20,000 different medicinal plants in 91 different countries [1]. Throughout time, many civilizations have used different species of these plants for their potential to treat diseases. That is the case of many species of plants from the Meliaceae family, which are used in traditional medicine and also in pest control. This family, distributed in tropical and subtropical regions, includes more than 50 genera with about 1400 species [2]. Of the various phytochemical constituents isolated from different parts of plants in this family, limonoids are the most relevant. Limonoids are described as exhibiting a range of biological activities, with insecticidal, antifungal, antimalarial, antibacterial, antiviral, and anticancer effects [3]. Besides the Meliaceae family, limonoids are also found in the Rutaceae family and, less frequently, in the Cneoraceae family [4]. More than 300 limonoids have been isolated and they are described as more abundant and diverse in the Meliaceae family than in any other family [2]. An important limonoid, gedunin (and/or a number of its derivatives), has been reported in various genera of the Meliaceae family, e.g., Azadirachta, Cabralea, Carapa, Cedrela, Chukrasia, Entandrophragm, Guarea, Trichilia, and Xylocarpus [5-7]. Gedunin is abundant in the fruit epicarp of Azadirachta indica A. Juss. and has higher concentrations in young green fruits than in ripe fruits [8]. A. indica leaves presented gedunin concentrations lower than $0.1 \%$ and a residual presence elsewhere in the plant. Several biological activities have been attributed to gedunin, such as antibacterial, antifungal, antimalarial, insecticidal, antiallergic, anti-inflammatory, anticancer, and neuroprotective effects (Figure 1) [4,9-11]. 


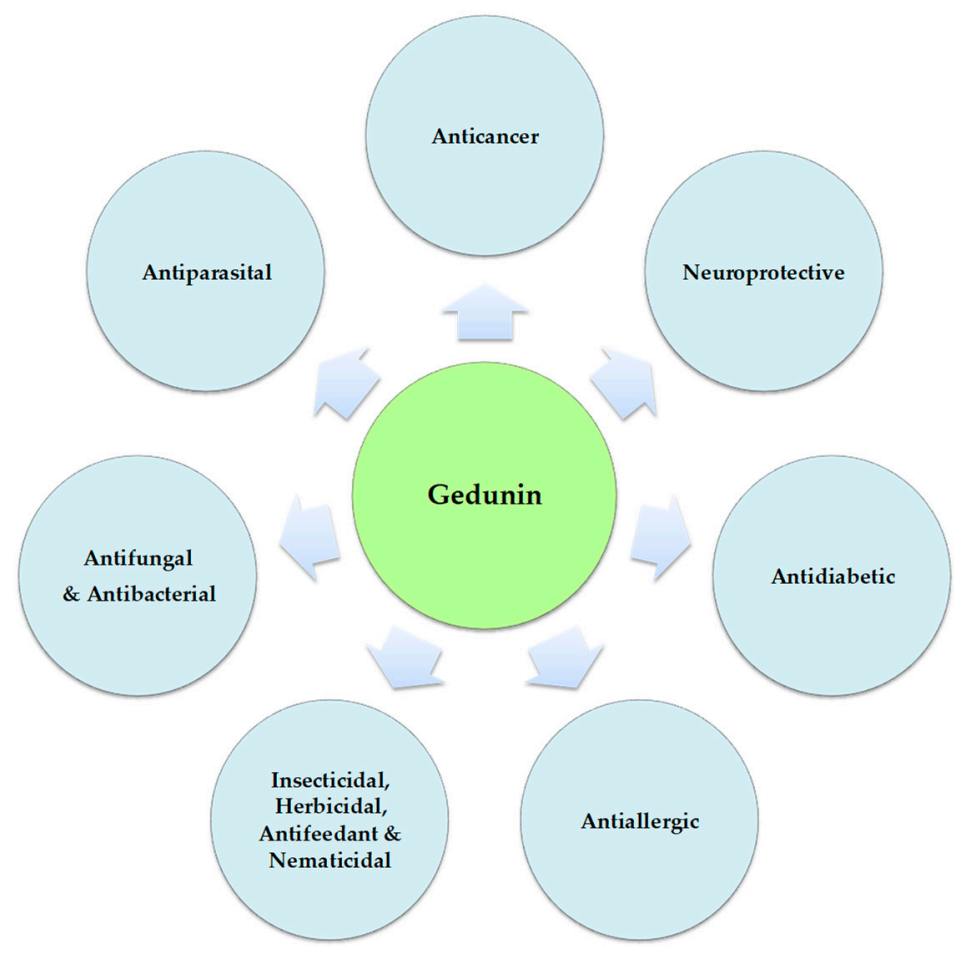

Figure 1. Biological activities of gedunin.

The present review aims to provide a state-of-the-art analysis about gedunin, focusing in the several biological activities described and the importance of this natural product in the development of new therapeutics. This manuscript represents, to our knowledge, the first review about this important limonoid from the Meliaceae family.

\section{Chemistry}

Structurally, limonoids are formed by loss of four terminal carbons of the side chain in the apotirucallane or apoeuphane skeleton and then cyclized to form the $17 \beta$-furan ring. This is why they are also known as tetranortriterpenoids [4], and classified according to which of the four rings (A, B, C and D), in the intact triterpene nucleus, was oxidized [12]. Gedunin is the most representative member of the ring D-seco class of limonoids. In this group, the $\delta$-lactone in ring $\mathrm{D}$ derived from the azadirone class undergoes a ring oxidative expansion through a Baeyer-Villiger type reaction, having a 4,4,8-trimethyl-17-furanyl steroid skeleton [4,13,14]. The biosynthetic pathway leading to the formation of gedunin from a tetranortriterpenoid is presented in Figure 2c. Several steps from this pathway are still uncharacterized. However, Aarthy et al. [15] recently discovered, for the neem tree, the crucial role of the mevalonic acid (MVA) pathway as the only source of isoprene units for limonoid biosynthesis, and that the amino acid isoleucine and leucine biosynthetic pathways contribute to the building of the functional groups of limonoids. The molecular formula of gedunin is $\mathrm{C}_{28} \mathrm{H}_{34} \mathrm{O}_{7}$ (MW: $482.55 \mathrm{~g} / \mathrm{mol}$ ), and it was first isolated from the West African timber Entandrophragma angolense (Welw.) C. DC. and named by Akisanya and his co-authors in 1960 [16,17]. Later, in 1961, the same authors described some reactions of gedunin, which were explained by a structure similar to that proven for limonin [17]. The application of nuclear magnetic resonance (NMR), mass spectrometry (MS), and X-ray diffraction analysis contributed to gedunin characterization, its constitution, and its relative stereochemistry, using a dihydrogedun-3 $\beta$-yl iodoacetate derivative [18-21]. These data confirm the chemical structure of gedunin presented in Figure 2a,b. 
a)

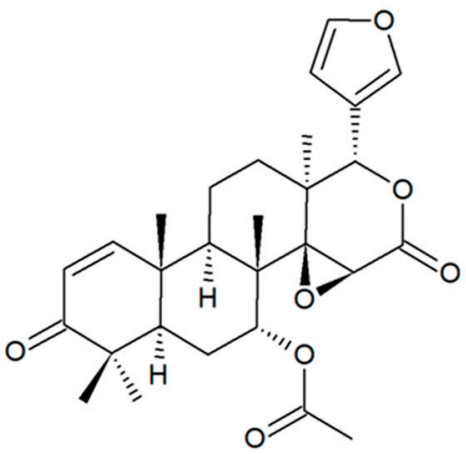

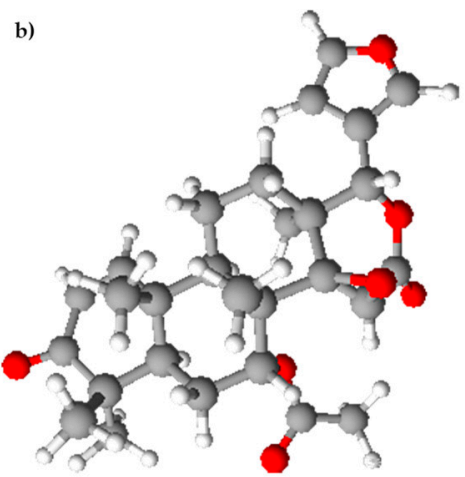

c)

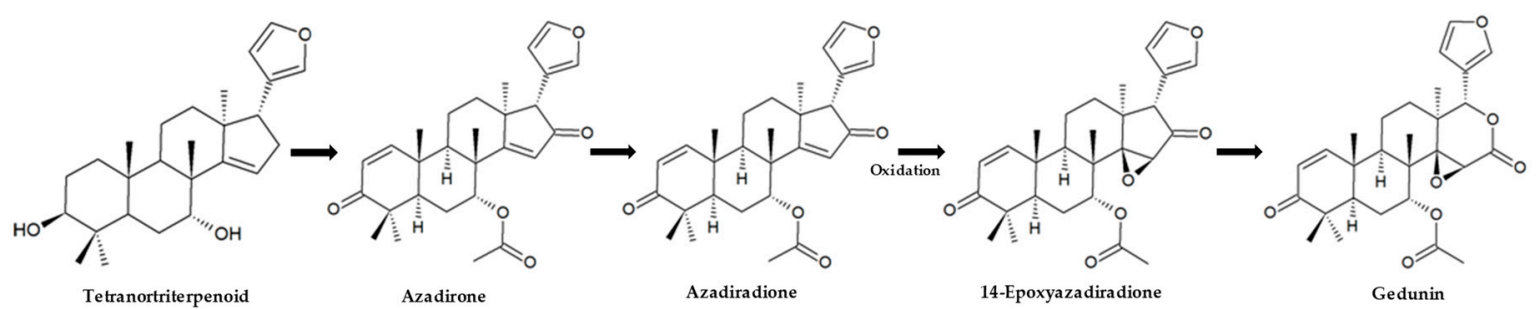

Figure 2. Chemical structure of gedunin: (a) Two-dimensional structural formula and (b) three-dimensional model; (c) Biosynthesis pathway of gedunin (adapted from Narender et al. [12] and Aarthy et al. [15]). ChemSketch software was used to create all chemical structures.

Gedunin, isolated from Trichilia pallida Sw., crystallizes in the orthorhombic space group $P 2{ }_{1} 2_{1} 2_{1}$, with two independent molecules in the asymmetric unit ( $\alpha$-Gedunin and $\beta$-Gedunin) [6]. Its asymmetric unit arrangement is described as being spontaneous and exothermically produced in the steps of crystallization. The molecular electrostatic potential (MEP) map revealed that the negative potential sites are around electronegative atoms, and the positive potential sites around the hydrogen atoms. The interaction between conformers is strong $(13.09 \mathrm{kcal} / \mathrm{mol})$.

The total synthesis of gedunin has not yet been reached. Semi-synthetic derivatives of gedunin have been successfully produced by chemical modifications to the gedunin scaffold, but they presented lower biological activity than the original compound [22-24]. Recent studies have achieved a full construct of the elaborated $\mathrm{ABC}$ ring system by using a Robinson annulation reaction, which facilitated the installation of the 7-acetoxy functional group and completion of the ring [25,26], and revealed the first synthetic route to the BCD ring system of the unsaturated ring D-seco limonoids [27].

\section{Biological Activities}

\subsection{Anticancer Activity}

Gedunin has been reported as an anticancer agent, mainly as a cell proliferation inhibitor and apoptosis inductor. This section presents several anticancer studies using gedunin (Table 1 ) and its importance as an inhibitor of heat shock protein 90 (Hsp90) activity. 
Table 1. Comparative anticarcinogenic properties of gedunin in different types of cancer.

\begin{tabular}{|c|c|c|c|c|c|c|c|}
\hline & \multirow{2}{*}{ Cancer Type } & \multirow{2}{*}{ Gedunin Source } & \multicolumn{2}{|c|}{ Type of Study } & \multirow{2}{*}{ Effect } & \multirow{2}{*}{ Mechanisms } & \multirow{2}{*}{ References } \\
\hline & & & In Vitro & In Vivo & & & \\
\hline \multirow{6}{*}{ 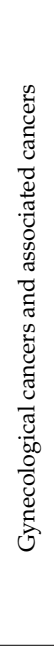 } & \multirow[b]{2}{*}{ Ovarian cancer } & \multirow[b]{2}{*}{ Commercial } & $\begin{array}{c}\text { SKOV3 } \\
\text { OVCAR4 } \\
\text { OVCAR8 }\end{array}$ & - & $\begin{array}{l}\text { Inhibits cell } \\
\text { proliferation }\end{array}$ & $\begin{array}{c}\text { An up to } 80 \% \text { decrease in cell proliferation; bioinformatic analysis } \\
\text { identified } 32 \text { genes involved }\end{array}$ & [28] \\
\hline & & & $\begin{array}{l}\text { ID8 } \\
\text { ID8TaxR } \\
\text { A2870 } \\
\text { C } 30 \\
\text { CP70 }\end{array}$ & - & $\begin{array}{l}\text { Inhibits cell } \\
\text { proliferation } \\
\text { Apoptosis } \\
\text { induction }\end{array}$ & $\begin{array}{l}\text { Induces mitotic arrest between metaphase and anaphase; changes the } \\
\text { expression of checkpoint kinase } 1 \text { (CHK1) and polo-like kinase-1 (PLK1); } \\
\text { decreases inhibitory phosphorylation (Y15) of cyclin dependent kinase } 1 \\
\text { (CDK1) and increases levels of cyclin B1; induces DNA fragmentation and } \\
\text { increases the Bcl-2 to B-cell lymphoma-2 protein associated X protein (Bax) } \\
\text { protein ratio and mitochondrial cytochrome c release }\end{array}$ & [29] \\
\hline & \multirow{4}{*}{$\begin{array}{l}\text { Breast and cervical } \\
\text { cancer }\end{array}$} & $\begin{array}{c}\text { Commercial neem } \\
\text { oil extract }\end{array}$ & $\begin{array}{c}\text { MCF-7 } \\
\text { SK-BR-3 } \\
\end{array}$ & - & $\begin{array}{l}\text { Inhibits cell } \\
\text { proliferation }\end{array}$ & Inhibits Hsp90 & [24] \\
\hline & & Commercial & $\begin{array}{l}\text { HeLa-PR } \\
\text { Hs578T } \\
\text { MCF-7 } \\
\text { MDA-MB-231 } \\
\text { MDA-MB-453 }\end{array}$ & $\begin{array}{l}\text { Mouse embryonic fibroblast } \\
\text { culture }\end{array}$ & $\begin{array}{l}\text { Apoptosis } \\
\text { induction }\end{array}$ & Mediates caspase- 7 cleavage of the co-chaperon p23 & [30] \\
\hline & & $\begin{array}{l}\text { Ground stem extract } \\
\text { (Cedrela odorata) }\end{array}$ & MCF-7 & - & $\begin{array}{c}\text { Exhibits cytotoxic } \\
\text { effects }\end{array}$ & - & [31] \\
\hline & & $\begin{array}{c}\text { Seed extract } \\
\text { (Azadirachta indica) }\end{array}$ & SK-BR-3 & - & $\begin{array}{c}\text { Exhibits cytotoxic } \\
\text { effects }\end{array}$ & - & {$[32,33]$} \\
\hline \multirow{5}{*}{ 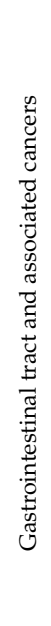 } & \multirow[b]{2}{*}{ Oral cancer } & \multirow[b]{2}{*}{ Commercial } & - & $\begin{array}{l}\text { Male Syrian hamsters with } \\
\text { 7,12-dimethylbenz(a)anthracene } \\
\text { (DMBA)-induced oral cancer }\end{array}$ & $\begin{array}{l}\text { Effects on tumor } \\
\text { invasion and } \\
\text { angiogenesis }\end{array}$ & $\begin{array}{l}\text { Inhibits kinases Akt, inhibitory kappa B kinase (IKK), and aldose } \\
\text { reductase (ARase), and the oncogenic transcription factors nuclear factor } \\
\text { kappa B (NF-kB) and hypoxia inducible factor } 1 \text { alpha (HIF1 } \alpha)\end{array}$ & [34] \\
\hline & & & SCC131 & - & $\begin{array}{l}\text { Inhibits cell } \\
\text { proliferation } \\
\text { Apoptosis } \\
\text { induction }\end{array}$ & $\begin{array}{l}\text { Blocks cell proliferation, invasion, and angiogenesis, and induces cell } \\
\text { death by blocking the ARase-driven oncogenic signaling network }\end{array}$ & [35] \\
\hline & Stomach cancer & $\begin{array}{l}\text { Seed extract } \\
\text { (A. indica) }\end{array}$ & AZ521 & - & $\begin{array}{c}\text { Exhibits cytotoxic } \\
\text { effects }\end{array}$ & - & [33] \\
\hline & Colon cancer & $\begin{array}{l}\text { Bark extract } \\
\text { (Xylocarpus } \\
\text { granatum) }\end{array}$ & $\mathrm{CaCo}-2$ & - & $\begin{array}{c}\text { Exhibits cytotoxic } \\
\text { effects }\end{array}$ & - & [5] \\
\hline & Pancreatic cancer & Commercial & $\begin{array}{l}\text { HPAC } \\
\text { MIAPaCa-2 } \\
\text { PANC-1 }\end{array}$ & $\begin{array}{l}\text { Female athymic nude mice with } \\
\text { HPAC-induced carcinogenesis }\end{array}$ & $\begin{array}{l}\text { Inhibits cell } \\
\text { proliferation } \\
\text { Apoptosis } \\
\text { induction } \\
\text { Effects on tumor } \\
\text { invasion and } \\
\text { angiogenesis }\end{array}$ & $\begin{array}{l}\text { Induces both intrinsic and extrinsic mediated apoptotic cell death; inhibits } \\
\text { the activation of phosphoinositide 3-kinases (PI3K) and its downstream } \\
\text { signaling by dephosphorylating PI3K at Tyr458/Tyr199, Serine/threonine } \\
\text { kinase (AKT) at Ser473, p70S6K at Thr389, and mammalian target of } \\
\text { rapamycin (mTOR) at Ser2448; inhibits metastasis of pancreatic cancer } \\
\text { cells by decreasing their epithelial-to-mesenchymal transition (EMT) as } \\
\text { well as invasive, migratory, and colony formation capabilities, and also } \\
\text { inhibits sonic hedgehog signaling pathways }\end{array}$ & [36] \\
\hline
\end{tabular}


Table 1. Cont.

\begin{tabular}{|c|c|c|c|c|c|c|}
\hline \multirow{3}{*}{ Prostate cancer } & \multirow{2}{*}{ Commercial } & \multirow{2}{*}{ LNCaP } & & \multirow{2}{*}{$\begin{array}{l}\text { Inhibits cell } \\
\text { proliferation }\end{array}$} & \multirow{2}{*}{$\begin{array}{c}\text { Inhibits heat shock protein } 90 \text { (Hsp90) activity } \\
\text { Inhibits Hsp90 activity and Hsp90 clients, } \\
\text { including androgen receptor }\end{array}$} & \multirow{2}{*}{$\begin{array}{l}37] \\
{[38]}\end{array}$} \\
\hline & & & - & & & \\
\hline & Not specified & Not specified & - & $\begin{array}{c}\text { Inhibits cell } \\
\text { proliferation } \\
\text { Apoptosis } \\
\text { induction }\end{array}$ & $\begin{array}{l}\text { Decreases expression of Hsp } 90 \text { and phosphorylation of mTOR, } 4 \mathrm{EBP} ; \\
\text { regulates LC3B, WIPI-1, VMP-1, pJNK, cleavage of caspases, and poly } \\
\text { (ADP-ribose) polymerase (PARP) }\end{array}$ & [39] \\
\hline \multirow[t]{3}{*}{ Lung cancer } & $\begin{array}{l}\text { Ground stems } \\
\quad \text { extract } \\
\text { (C. odorata) }\end{array}$ & NCI-H460 & - & $\begin{array}{c}\text { Exhibits cytotoxic } \\
\text { effects } \\
\text { Inhibits cell } \\
\text { proliferation } \\
\text { Apoptosis } \\
\text { induction } \\
\end{array}$ & Causes cell cycle arrest at the $S$ phase and induces apoptosis. & [31] \\
\hline & Commercial & A-549 & - & $\begin{array}{l}\text { Apoptosis } \\
\text { induction }\end{array}$ & $\begin{array}{l}\text { Hsp90 inhibition regulates the PI3K/AKT signaling pathway, inhibits } \\
\text { autophagy, and induces apoptosis in cells }\end{array}$ & [40] \\
\hline & $\begin{array}{c}\text { Commercial } \\
\text { nano-encapsulated }\end{array}$ & NCI-H292 & - & $\begin{array}{l}\text { Inhibits cell } \\
\text { proliferation } \\
\text { Apoptosis } \\
\text { induction }\end{array}$ & $\begin{array}{c}\text { Enhances anti-proliferative effects against cells through } p 53 \text {-initiated, } \\
\text { Bax-associated, caspase-dependent activation of apoptosis }\end{array}$ & [41] \\
\hline Brain cancer & Commercial & U-251 MG & - & $\begin{array}{l}\text { Effects on tumor } \\
\text { invasion and } \\
\text { angiogenesis }\end{array}$ & $\begin{array}{c}\text { Inhibits proliferation, migration and invasive potential of the cells through } \\
\text { inhibition of matrix metallopeptidase } 9 \text { (MMP-9), focal adhesion kinase } \\
\text { (FAK), and Rho-associated protein kinase } 1 \text { (ROCK-1) }\end{array}$ & [42] \\
\hline \multirow{2}{*}{ Leukemia } & $\begin{array}{c}\text { Flower extract } \\
\text { (Carapa guianensis) }\end{array}$ & $\begin{array}{l}\text { P388 } \\
\text { HL60 }\end{array}$ & - & $\begin{array}{l}\text { Exhibits cytotoxic } \\
\text { effects }\end{array}$ & - & [43] \\
\hline & $\begin{array}{l}\text { Seed extract } \\
\text { (A. indica) }\end{array}$ & HL60 & - & $\begin{array}{l}\text { Exhibits cytotoxic } \\
\text { effects }\end{array}$ & - & {$[32,33]$} \\
\hline \multirow[b]{2}{*}{ Skin cancer } & $\begin{array}{l}\text { Ground stem extract } \\
\text { (C. odorata) }\end{array}$ & A375-C5 & - & $\begin{array}{c}\text { Exhibits cytotoxic } \\
\text { effects }\end{array}$ & - & [31] \\
\hline & $\begin{array}{l}\text { Seed extract } \\
\text { (A. indica) }\end{array}$ & B16 & - & $\begin{array}{l}\text { Exhibits cytotoxic } \\
\text { effects } \\
\text { Inhibits activity }\end{array}$ & - & {$[32,44]$} \\
\hline Cancer stem cells & Commercial & NTERA-2 & - & $\begin{array}{c}\text { Inhibits cell } \\
\text { proliferation } \\
\text { Apoptosis } \\
\text { induction }\end{array}$ & $\begin{array}{l}\text { Enhances anti-proliferative effect in cells; inhibits Hsp90 and survivin; } \\
\text { upregulates Bax and p53; induces DNA fragmentation and increases } \\
\text { caspase-3, caspase-7 activity }\end{array}$ & [45] \\
\hline
\end{tabular}




\subsubsection{Heat Shock Protein 90 Inhibition Activity}

Hsp90, one of the most abundant proteins in cells, is an adenosine triphosphate (ATP)-dependent molecular chaperone and is induced when a cell suffers several environmental stresses, such as cold, heat, or lack of oxygen [46,47]. It is involved in the turnover, trafficking, and activity of various oncogenic proteins (usually referred as "client proteins") including apoptotic factors, transcription factors, protein kinases, signaling proteins, and a number of oncoproteins. It has also been described to be associated to some neurodegenerative, vascular, and metabolic diseases. Recently, some plant-derived small molecules, such as gedunin, have been proved to exhibit inhibitory activity towards Hsp90. This was described for the first time by Lamb et al. [37], who discovered that gedunin exhibited antiproliferative activity by modulating Hsp90. The same authors later described gedunin as an androgen receptor (AR)-mediated signaling inhibitor and predicted that it also acted as an Hsp90 pathway inhibitor, promoting client protein degradation and the activation of heat shock factor 1 (HSF1) [38]. At that time, a new mechanism of action of Hsp90 inhibitor was proposed for gedunin, outside the N-terminal ATP-binding pocket. Gedunin was also verified as a disruptor of Hsp 90 co-chaperone encoded by the CDC37 gene (Cdc37)/Hsp90 interactions through modulation of Hsp90 [48]. Gedunin's cytotoxic effect is due to its binding to p23 co-chaperone of Hsp90. This interaction inactivates Hsp90, which leads to destabilization of its client proteins. Computational modeling showed that gedunin forms hydrogen bond contacts with Thr 90 and Lys 95 at the C-terminal region of p23 and forms hydrophobic interactions with side chain of Ala 94 [30]. Recently, in order to better understand the likely mode of binding between gedunin and p23, a docking study was performed which revealed that the furan moiety of this compound forms hydrogen bonds with the side chain of Thr 90 and that Lys 95 hydrogen bonds with the epoxide of gedunin (docking score of 49) [27]. The anticancer effect of gedunin, as an Hsp90 inhibitor, will be discussed in detail for each type of cancer in its respective section.

\subsubsection{Gynecologic Cancers and Associated Cancers}

Ovarian cancer is the fifth leading cause of death among women [49]. The first approach to the effect of gedunin on ovarian cell line was performed by Kamath et al. [28]. These authors studied the in vitro effect of gedunin on SKOV3, OVCAR4, and OVCAR8 ovarian cancer cell line proliferation, alone and in the presence of cisplatin. Their results revealed a noticeable decrease in cell proliferation after treatment with gedunin alone by more than $80 \%(p<0.01)$, and with gedunin combined with cisplatin a decrease up to $47 \%$ compared with cisplatin treatment alone. In this study a bioinformatic analysis of integrated gedunin sensitivity and gene expression data was also carried out, with the discovery of 52 genes involved and related to modulation of cell survival and apoptosis pathways. The anti-proliferative potential of gedunin has also been investigated using the ID8, ID8TaxR, A2870, C30, and CP70 ovarian cancer cell lines [29]. In this study, the treatment with gedunin inhibited growth of all cell lines, and synergism between gedunin and paclitaxel was detected even at low concentrations ( $2.5 \mu \mathrm{M}$ for each), which were not effective on cells when using each compound alone. Johnson et al. [29] were able to demonstrate that gedunin induced mitotic arrest between metaphase and anaphase, changing the expression of checkpoint kinase-1 (CHK1) and polo-like kinase-1 (PLK1) and resulting in apoptosis. It was also reported that gedunin-treated cells: (1) decreased inhibitory phosphorylation (Y15) of cyclin dependent kinase 1 (CDK1) and increased levels of cyclin B1, compared to untreated cells; (2) formed double-strand breaks; and (3) and increased the Bcl-2 to Bax protein ratio and mitochondrial cytochrome c release.

Breast cancer is the most common cancer among women of reproductive age [49]. The antiproliferative activity of gedunin against MCF-7 and SkBr3 breast cancer cells lines is reported by Brandt et al. [24]. In this study, gedunin, isolated from commercial neem oil, presented half maximal inhibitory concentration $\left(\mathrm{IC}_{50}\right.$ ) values of 8.8 and $3.3 \mu \mathrm{M}$ for MCF-7 and SkBr3, respectively. The effectiveness of gedunin, extracted from ground stems of Cedrela odorata L. grafted on Toona cilata var. australis (F. Muell.) Bahadur, against MCF-7 was also focused on in another study, where it 
presented a strong cell growth inhibitory activity against these cells (median growth inhibition concentration, $\mathrm{GI}_{50}=9.1 \mu \mathrm{M}$ ) [31]. Two other studies evaluated the cytotoxic activity of gedunin, extracted from $A$. indica seed, against human breast cancer cell line SK-BR-3 and both found an $\mathrm{IC}_{50}$ value of $8.3 \mu \mathrm{M}[32,33]$. Patwardhan et al. [30] revealed that gedunin induced cancer cell death in cervical (HeLa-PR ${ }_{B}$ ) and breast carcinoma (MDA-MB-231, MDA-MB-453, Hs578T, T47D, and MCF-7) cell lines in a dose-dependent manner and selectively killed the cancer cells. These authors showed that the death pathway triggered by gedunin in MCF-7 and HeLa-PR ${ }_{\mathrm{B}}$ cells was through caspase-7 activation and poly (ADP-ribose) polymerase (PARP) cleavage. By computational modeling, they revealed that gedunin can be successfully docked into the p23 structure, and that three amino acids (Thr-90, Ala-94, and Lys-95) can possibly mediate noncovalent interactions with the natural compound. Thus, Pathwardhan et al. [30] concluded that gedunin: (1) directly binds to p23 and inactivates it, without overexpression of Hsp27 and relatively modest induction of Hsp70; and (2) inhibits the p23 chaperoning activity, blocks its cellular interaction with Hsp90, and interferes with p23-mediated gene regulation. This leads to cancer cell death by apoptosis through inactivation of p23 and activation of caspase-7, which cleaves $\mathrm{p} 23$ at the $C$ terminus.

These studies suggest that the treatment with gedunin, alone or combined with other chemotherapeutic drugs, can lead to promising results against gynecological and associated cancers.

\subsubsection{Gastrointestinal Tract and Associated Cancers}

Gedunin's effect on oral cancer has been recently studied in vitro [35] and in vivo [34]. The in vivo approach investigated the effects of gedunin on the phosphoinositide 3-kinases (PI3K)/Akt/mammalian target of rapamycin (mTOR) and nuclear factor kappa B (NF- $\mathrm{kB}$ ) signaling pathways, as well as hypoxia-inducible factor $1 \alpha$ (HIF1 $\alpha$ )-mediated vascular endothelial growth factor (VEGF) signaling in a hamster buccal pouch (HBP) carcinogenesis model. For that, male Syrian hamsters with dimethylbenz(a)anthracene (DMBA)-induced oral cancer received intragastric administration of gedunin at different concentrations. It was observed that administration of gedunin, at $100 \mu \mathrm{g} / \mathrm{kg}$ bw), significantly $(p<0.01)$ reduced tumor incidence, and only mild hyperplasia was observed in the buccal pouches of the animals. Nagini and his co-workers [34] concluded that suppression of HBP was caused by inhibition of PI3K/Akt and NF- KB pathways through inactivation of Akt and inhibition of kappa B kinase (IKK), respectively, due to the inactivation of the aldose reductase (ARase) by gedunin. It blocked the angiogenesis by downregulating the expression of microRNA-21 (miR-21) and the pro-angiogenic factors vascular endothelial growth factor and HIF- $1 \alpha$.

The in vitro approach used the SCC131 oral cancer cell line to investigate how gedunin, alone or combined with epalrestat, prevented the hallmarks of cancer by inhibiting ARase and the associated downstream PI3K/Akt/mTOR/ERK/NF-kB signaling axis. Tanagala et al. [35] concluded that gedunin, alone and combined, blocked cell proliferation, invasion, and angiogenesis, and induced cell death by blocking ARase-driven oncogenic signalling networks. Furthermore, gedunin combined with epalrestat was more effective than each single agent, suppressing the growth of SCC131 cells at half the concentrations used individually ( 0 to $180 \mu \mathrm{M}$ for gedunin and 0 to $1.6 \mu \mathrm{M}$ for epalrestat) [35].

Gedunin isolated from $A$. indica seed extract was evaluated for its cytotoxic activity against human stomach cancer cell line SK-BR-3 [33]. It presented moderate effectiveness against these cells, with an $\mathrm{IC}_{50}$ value of $16.9 \mu \mathrm{M}$. Moderate levels of cytotoxic activity were also observed on the CaCo-2 colon cancer cell line, tested with gedunin isolated from bark of Xylocarpus granatum J. Koenig, with an $\mathrm{IC}_{50}$ value of $16.8 \mu \mathrm{M}$ [5]. Recently, Subramani et al. [36] studied the anti-proliferative effect of gedunin on pancreatic cancer cell lines (HPAC, PANC-1, and MIAPaCa-2), showing that it induced about $50 \%$ cell death at $25 \mu \mathrm{M}$ in all of them. The same treatment revealed to induce apoptosis in all tested cancer cell lines with an increased expression of the pro-apoptotic markers Bax, as well as cleaved caspase-3, cleaved PARP, and cleaved caspase- 8 , and decreased in Bcl-2 expression. This means that gedunin induced both intrinsic and extrinsic mediated apoptotic cell death. In this study, Subramani et al. [36] showed that gedunin, at $15 \mu \mathrm{M}$, was able to inhibit the migratory abilities of all pancreatic cancer cells 
tested. The compound was also able to reduce the survival of pancreatic cancer cells by inhibiting the activation of PI3K and its downstream signaling via dephosphorylating PI3K at Tyr458/Tyr199, AKT at Ser473, p70S6K at Thr389, and mTOR at Ser2448. This study also showed that gedunin could inhibit three essential metastatic events, namely migration, invasion, and colony formation in pancreatic cancer cells, through epithelial-to-mesenchymal transition (EMT) inhibition due to the decrease in the expression of mesenchymal markers N-cadherin, Slug, Snail, vimentin, Notch 1 and 2, and Zeb increase in the expression of epithelial marker E-cadherin.

These different studies show that more research on gedunin as a new chemotherapeutic drug for gastrointestinal tract and associated cancers could be an interesting pathway to inhibit cancer cell proliferation, increase apoptosis, and, at the same time, inhibit metastatic characteristics of cancer cells, especially of the pancreas and mouth.

\subsubsection{Prostate Cancer}

The effect of gedunin on prostate cancer was assessed by Lamb et al. [37], who intended to elucidate the mechanism of action of gedunin as an AR inhibitor through a so-called Connectivity Map, using LNCaP cells. High connectivity scores were found for multiple instances of three Hsp90 inhibitors: (1) geldanamycin; (2) 17-allylamino-geldanamycin; and (3) 17-dimethylamino-geldanamycin, which had marked connectivity to the gedunin signature. Hsp90-interacting proteins were nearly entirely eliminated in gedunin-treated LNCaP, which means that gedunin was acting as an inhibitor of Hsp90 function, and was thus hypothetically inhibiting AR expression (as its stability is dependent on Hsp90 activity). Later, using a similar approach and the LNCaP cell line as well, it was shown that gedunin inhibited Hsp90 activity and Hsp90 clients, including AR [38]. Boopalan et al. [39] demonstrated that gedunin inhibited the growth of cancer cells and decreased the expression of Hsp90 and phosphorylation of mTOR and 4EBP. Gedunin also induced autophagy and apoptosis simultaneously by regulating key factors like LC3B, WIPI-1, VMP-1, pJNK, cleavage of caspases, and PARP.

\subsubsection{Lung Cancer}

Gedunin extracted from ground stems of $C$. odorata showed a strong cell growth inhibitory activity against non-small cell lung cancer NCI-H460, with a $\mathrm{GI}_{50}$ value of $8.36 \mu \mathrm{M}$ [31]. In this study, the underlying mechanism of the growth inhibitory activity of gedunin was also investigated for its effects on cell cycle profile and NCI-H460 programmed cell death. Cazal et al. [31] concluded that gedunin arrested the cell cycle progression in the $S$ phase, leading to a decrease in the percentage of cells in the G1 phase, thus inducing apoptosis. Recently, the anti-proliferative activity of free and nanoencapsulated gedunin against human non-small-cell lung cancer (NCI-H292) cells was investigated by Nwokwu et al. [41], demonstrating that liposomal gedunin has greater anti-proliferative effects in NCI-H292 cells than free gedunin, with $\mathrm{IC}_{50}$ values ranging from 3.4 to $1.8 \mu \mathrm{g} / \mathrm{mL}$ ( 24 to $72 \mathrm{~h}$ ) and 26.4 to $21.6 \mu \mathrm{g} / \mathrm{mL}$ ( 24 to $72 \mathrm{~h}$ ), respectively. These authors also studied the apoptotic effect of gedunin-loaded liposomal nanoparticles in NCI-H292 cell line and concluded that it enhances anti-proliferative effects through $p 53$-initiated, Bax-associated, caspase-dependent activation of apoptosis. Another recent study, by Hasan et al. [40], demonstrated that gedunin exerts cytotoxic effects on A549 cells in a dose-dependent manner after $24 \mathrm{~h}$ of treatment, and that this cytotoxic potential was in agreement with hallmarks of apoptosis, as gedunin increased reactive oxygen species (ROS) generation by 8.2 fold, loss in mitochondrial membrane potential by 3.6-fold, and increased chromatin condensation by 5.3 fold, as compared to the untreated control. These authors concluded that gedunin, as an inhibitor of Hsp90, regulates the PI3K/AKT signaling pathway, inhibits autophagy, and induces apoptosis in lung cancer cells.

These different studies show that gedunin, encapsulated or not, should be taken into consideration as a new possible therapeutic agent of non-small-cell lung carcinoma. 


\subsubsection{Brain Cancer}

Glioma is the most frequently detected primary brain tumor found in adults [50]. Recently, $\mathrm{Li}$ et al. [42] studied the effect of gedunin on viability, migration, and invasion of the U-251 MG cell line. Gedunin, at $20 \mu \mathrm{M}$, reduced the viability of the cells to $28 \%$ and significantly $(p<0.002)$ inhibited their invasive and migratory tendency. It also caused inhibition of MMP-9, Rho-associated protein kinase 1 (ROCK-1), and focal adhesion kinase (FAK) mRNA expression, as well as significant reduction of uPA protein expression. Therefore, gedunin can be considered as a possible new agent for the treatment of glioma.

\subsubsection{Leukemia}

Cytotoxic activity of gedunin, from $A$. indica seed extract, was evaluated against human leukemia cell line HL60, and an $\mathrm{IC}_{50}$ value of $5.9 \mu \mathrm{M}$ was observed [32,33]. Sakamoto et al. [43] using gedunin extracted from Carapa guianensis Aubl. flower oil, assessed its cytotoxicity against murine P388 leukaemia and HL60 cell lines, and obtained IC $_{50}$ values of 16 and $15.2 \mathrm{mM}$, respectively.

\subsubsection{Skin Cancer}

The B16 murine melanoma cell culture model was used to investigate cytotoxic effect of gedunin extract from the seeds of $A$. indica. Gedunin treatment $(25 \mu \mathrm{g} / \mathrm{mL})$ resulted in moderate melanogenesis inhibitory activity and cytotoxicity, a 93\% reduction of melanin content, and 13\% cell viability, respectively [44]. A similar study revealed that gedunin treatment $(10 \mu \mathrm{g} / \mathrm{mL})$ resulted in a $72 \%$ reduction of melanin content and 85\% cell viability, with an activity-to-cytotoxicity ratio of 0.34 [32], thus presenting a melanogenesis-inhibitory activity. Gedunin extracted from ground stems of $C$. odorata showed a strong cell growth inhibitory activity against melanoma cell line A375-C5, with a $\mathrm{GI}_{50}$ value of $8.8 \mu \mathrm{M}[31]$.

\subsubsection{Cancer Stem Cells}

Cancer stem cells (CSCs) are considered as initiators of tumor development and progression, as they can renew themselves indefinitely, generate new tumors, and cause metastasis and relapse [51]. An in silico molecular docking simulation with gedunin was carried out for its binding with receptor proteins involved in the main signaling pathways of CSCs and revealed a drug likeness of gedunin with $\beta$-catenin chain A in cancer stem cells [52]. The in vitro effectiveness of gedunin on human embryonal carcinoma (NTERA-2) cells, as a cancer stem cell model, was later evaluated, indicating a dose- and time-dependent inhibition of NTERA-2 cell proliferation treated with gedunin [45]. The compound also exerted a potential anti-proliferative effect on these cells, with $\mathrm{IC}_{50}$ values of $14.59,8.49$, and $6.55 \mu \mathrm{g} / \mathrm{mL}$ at 24,48 , and $72 \mathrm{~h}$ after incubations, respectively. Gedunin inhibited the expression of Hsp90, its client proteins, and survivin, and upregulated Bax and $p 53$. The apoptotic effect of gedunin was confirmed by DNA fragmentation, with increased caspase- 3 and caspase-7 activity and morphological changes related to apoptosis. These results revealed that gedunin may be a good candidate for the development of CSC-targeted anti-cancer drugs.

\subsection{Neuroprotective Activity}

Neuroprotection is the relative protection of neural structure and/or function. Many central nervous system (CNS) disorders have common mechanisms, such as oxidative stress, excitotoxicity, inflammatory changes, and mitochondrial dysfunction [53].

The Hsp90 complex has long been associated with neuropathological phenotypes related to Parkinson's disease (PD) and its inhibition in neuroprotective in disease models. Prolyl hydroxylase domain protein 2 (PHD2) is the primary regulator of steady-state levels of the transcription factor HIF1 $\alpha$. PHD2 levels have been reported to be elevated within affected substantia nigra pars compacta $(\mathrm{SNpc})$ tissues isolated from PD patients in conjunction with reductions in HIF1 $\alpha$ levels [54]. The Hsp90 
co-chaperone p23 is able to recruit and stabilize PHD2, thus reducing HIF1 $\alpha$ neuroprotective effect levels and its targets. Recently, the p23 inhibitor gedunin was found to protect against neurotoxicity associated with 1-methyl-4-phenylpyridine $\left(\mathrm{MPP}^{+}\right.$) in dopaminergic (DAergic) N27 cells [55]. Gedunin binds to $\mathrm{p} 23$ and prevents its interaction with Hsp90, thus inhibiting Hsp90 chaperone activity, without interfering with any other known Hsp90 co-chaperons. Gedunin could provide a new alternative in the treatment of PD, which may have fewer broad effects than other Hsp90 inhibitors.

Alzheimer's disease (AD) is one of the most common neurodegenerative disorders worldwide. Histopathological hallmarks of AD include extracellular amyloid plaques and intracellular neurofibrillary tangles (NFTs). Their accumulation leads to neurodegeneration in the hippocampus and cortex, and activation of microglia cells. In progressive brain damage, these cells can become chronically activated, resulting in a sustained aberrant inflammatory response [56]. Taking this into consideration, and knowing that gedunin has been: (1) proven to have neuroprotective effects against the toll-like receptor (TLR)-mediated inflammation (TLR2, TLR3, and TLR4) through the regulation of proinflammatory inflammasome activation and cytokine production [57,58]; and (2) has also been reported as a nuclear factor erythroid 2-related factor 2 (Nrf2) activator, inducing astrocyte-dependent neuroprotection from oxidative stress via a Nrf2-dependent mechanism [59], Tom et al. [56] studied the effect of gedunin on oligomeric $A \beta_{1-42}$-induced microglial activation and subsequent inflammation. From this study, three main conclusions can be highlighted: (1) gedunin suppressed, in a microglial cell line, neuroinflammation arising from $A \beta_{1-42}$ oligomer exposure, inducing NF- $\mathrm{kB}$ activation and its targets, including nitric oxide (NO) and IL-1 $\beta$ (interleukin 1, beta); (2) gedunin inhibited neuroinflammation by activating Nrf2 and its downstream targets $\gamma$-glutamylcysteine synthetase, heme oxygenase 1 , and NADPH quinone dehydrogenase 1 , involved in quenching reactive oxygen and nitrogen species generated by NF-KB activation; and (3) gedunin prevented, in human neuronal cells (SH-SY5Y), neurotoxicity secondary to A $\beta$-induced microglial activation. Hereupon, gedunin can be seen as a natural alternative therapy against neurodegenerative diseases such as AD.

\subsection{Antidiabetic Activity}

Diabetes mellitus (DM) is a metabolic disorder caused by a defect in the insulin secretion and/or action, leading to chronic hyperglycemia [60]. Human pancreatic $\alpha$-amylase (HPA) is a key enzyme in the digestive system and plays an important role in DM [61]. It catalyzes the initial step in the hydrolysis of starch, which is a principal source of glucose in the diet. Thus, HPA inhibitors present an effective strategy to lower postprandial hyperglycemia by controlling starch breakdown [61]. Recently, neem limonoids, including gedunin, were screened and identified as potent inhibitors of HPA, based on their inhibition potency and in vitro cytotoxicity, and studied in order to identified their mode of action and underlying molecular interactions [62]. In this study, gedunin presented promising results as an HPA inhibitor. Gedunin exhibited a porcine pancreatic $\alpha$-amylase inhibition $\mathrm{IC}_{50}$ value of $72.2 \mu \mathrm{M}$, cytotoxicity at an $\mathrm{IC}_{50}$ value of $13.4 \mu \mathrm{M}$ for AR42J cell line, and amylase inhibition of $69.2 \%$, with maximal secreted $\alpha$-amylase inhibition of $53.4 \%$ seen at $3.3 \mu \mathrm{M}$. In silico screening of gedunin docked onto HPA revealed a minimal energy of interaction of $-25.9 \mathrm{~kJ} / \mathrm{mol}$ and the involvement of a pi-alkyl interaction between Trp 58 and the C29 methyl of the A ring, with a bond length of $5.30 \AA$ A. This suggests that any substitution in the A ring may interfere in gedunin binding to HPA. In this study, gedunin inhibited HPA with sigmoidal fit with an $\mathrm{IC}_{50}$ value of $68.38 \mu \mathrm{M}$, and the Michaelis-Menten kinetics suggested a mixed mode of inhibition with maltopentose $(\mathrm{Ki} 18.6 \mu \mathrm{M})$ and starch $(\mathrm{Ki} 37.4 \mu \mathrm{M})$ as a substrate with a stoichiometry of 1:1. Results also suggested that gedunin likely binds near the active pocket. However, the active site residues were not involved in their binding. Fluorescence and circular dichroism spectroscopy confirmed the involvement of tryptophan and tyrosine in ligand binding to HPA. The interaction between HPA and gedunin was a spontaneous process with free energy decreasing; the binding was enthalpically and entropically driven with $\Delta \mathrm{G}^{\circ}$ of $-21.16 \mathrm{~kJ} / \mathrm{mol}$. Thus, gedunin can be seen as a HPA inhibitor molecule and it can aid in the design of 
better drug candidates with newer inhibitors of HPA for controlling starch digestion in order to reduce post-prandial hyperglycemia.

\subsection{Antiallergic Activity}

Allergy is characterized by a strong inflammatory response involving several mediators and cell types [63]. Oil extracted from C. guianensis seeds, containing gedunin, among other effects, inhibited edema formation during the allergic response in vivo [64]. This property was shown to be mediated by the inhibition of major inflammatory mediators involved in vascular permeability, such as histamine, platelet activating factor (PAF) and bradykinin. This oil also inhibited allergic eosinophilia, which is correlated with the inhibition of CCL11/eotaxin and IL-5 generation through the NFKB signaling pathway impairment in mice [65]. Ferraris et al. [63] revealed that gedunin has an important antiallergic activity in in vivo models of allergic airway inflammation, achieved by both pre- and post-treatments with gedunin. This effect showed to be mediated by the inhibition of chemotactic mediators involved in $\mathrm{T}$ cell and eosinophil migration. Gedunin directly modulated $\mathrm{T}$ lymphocyte activation and trafficked into the airways, which is critical for the development and maintenance of the inflammatory allergic response. Regarding these studies, it can be said that gedunin might represent a potential therapeutic tool to suppress allergic features and control allergic diseases.

\subsection{Insecticidal, Herbicidal, Antifeedant, and Nematicidal Activity}

Natural pesticides are biodegradable and eco-friendly, as some are described as having less environmental impact than most commercial chemical insecticides [66]. Gedunin's properties as a biopesticide have long been tested against Spodoptera frugiperda and it proved to cause significant larval mortality, as well as growth reduction, with a half maximal effective concentration $\left(\mathrm{EC}_{50}\right)$ ranging from 10 to 39 ppm [14,67-71]. Gedunin's antifeedant activity against Cnaphalocrocis medinalis was widely studied. Gedunin not only affects $C$. medinalis growth and larval behavior, but also affects its gut enzyme activity, such as acid phosphatases (ACP), alkaline phosphatases (ALP), adenosine triphosphatases (ATPase), and lactate dehydrogenase (LDH) [66,72-74]. The half maximal lethal concentration ( $\left.\mathrm{LC}_{50}\right)$ value obtained for gedunin against the fourth-instar larvae of Anopheles stephensi was 120 ppm [75]. For the same agent, the larvicidal, pupicidal, adulticidal, and antiovipositional activity of gedunin was studied, and it presented biological activity at high doses and the $\mathrm{EC}_{50}$ against first to fourth instar larvae of A. stephensi ranged from 0.058 to $0.117 \mathrm{ppm}$ [76]. Gedunin has also been tested against Ostrinia nubilalis, presenting antifeedant activity at 10-50 ppm [77,78]. Reticulitermes speratus presented growth inhibition in the presence of gedunin $\left(\mathrm{PC}_{95}=218.4 \mu \mathrm{g} / \mathrm{disc}\right)$ and of a mixture of limonoids containing gedunin $\left(\mathrm{PC}_{95}=0.35 \% w / w\right)$, isolated from a neem oil extract $[79,80]$. For Helicoverpa armigera, gedunin presented $\mathrm{EC}_{50}$ between 3.51 and $50.8 \mathrm{ppm}$ and for Spodoptera litura an $\mathrm{EC}_{50}$ of $40.4 \mathrm{ppm}[81,82]$. Gedunin was also proven active against Sitophilus oryzae at 0.50\% (w/w) [83], Pectinophora gossypiella, and Heliothis zea, with an $\mathrm{EC}_{50}$ of 32 and 50 ppm, respectively [67].

More recently, gedunin's toxic action against instar larvae of Aedes aegypti, the mosquito responsible for transmission of yellow fever and dengue fever, and of Culex quinquefasciatus, the mosquito responsible for filariasis transmission, was determined. Gedunin, isolated from neem seed kernel oil, exhibited $100 \%$ toxic action against both mosquito larvae at 50 and $100 \mathrm{ppm}$ [84]. The pesticidal activity of gedunin was tested in four different insects, Nilaparvata lugens, Myzus persicae, S. litura, and Plutella xylostella [85]. It showed insecticidal activity to $N$. lugens with 40,20 , and $0 \%$ mortality at concentrations of $1,0.5$, and $0.25 \mathrm{mg} / \mathrm{mL}$, respectively, and moderate activity against $P$. xylostella, with 60,40 , and $10 \%$ mortality at concentrations of $1,0.5$, and $0.25 \mathrm{mg} / \mathrm{mL}$, respectively. Gedunin did not show insecticidal or larvicidal activities against $S$. litura and M. persicae. Due to its recognized power as a natural insect growth inhibitor, gedunin has also been commonly used as a positive control in several antifeedant activity studies against $S$. frugiperda, Drosophila melanogaster, Acanthoscelides obtectus, and Epilachna varivestis [86-89]. 
Other bioactivities have been tested on gedunin, namely nematicidal and herbicidal activities. In the first case, gedunin was tested with Meloidogyne incognita and presented $40 \%$ mortality at 100 ppm [90]. In the second case, etiolated wheat coleoptile bioassay, which detects the effects on development of non-differentiated vegetal cells, was used to evaluate phytotoxicity of gedunin, isolated from the stem of C. odorata grafted onto T. ciliata var. australis [91]. The compound presented a good inhibition effect for all tested concentrations, with an $\mathrm{IC}_{50}$ of $2.642 \mu \mathrm{M}$, and thus was selected for phytotoxicity evaluation on the standard target species (STS) Lepidium sativum L. (cress), Lactuca sativa L. (lettuce), Lycopersicon esculentum Mill. (tomato), and Allium cepa L. (onion). Gedunin affected the root growth of L. sativum, at all tested concentrations, with similar levels to that of the herbicide Logran ${ }^{\circledR}$ (used as positive control). However, its behavior was not significant for the other STS.

Gedunin extracted from different plants of the Meliaceae family, neem (seeds, oil) and Cedrela species (wood, stem) proved to be effective at eradicating several larvae. This way, gedunin can be considered an eco-friendly pest management tool.

\subsection{Antibacterial and Antifungal Activity}

Antifungal activity of gedunin was first tested against Polyporus palustris and Polyporus versicolor [92]. Gedunin, isolated from Xylocarpus obovatus A. Juss., showed a marked and progressive antifungal activity, with $P$. palustris being more sensitive than P. versicolor. More recently, fungicidal activity of gedunin was determined against six phytopathogenic fungi: Pyricularia grisea, Rhizoctonia solani, Botrytis cinerea, Phytophthora infestans, Puccinia recondite, and Erysiphe graminis [85]. In this study, the whole plant method was used for three different gedunin concentrations: $1,0.5$, and $0.25 \mathrm{mg} / \mathrm{mL}$. Gedunin only exhibited antifungal activities of 40 and $20 \%$ to P. recondite, at concentrations of 1 and $0.5 \mathrm{mg} / \mathrm{mL}$, respectively. Antibacterial activity of gedunin was determined for a Gram-negative bacterium, Xylella fastidiosa, which presented a minimum inhibitory concentration (MIC) value of $2.7 \times 10^{3} \mu \mathrm{M}[93]$.

Gedunin has been proved to have antifungal and antibacterial activity. Although, more tests could be performed and gedunin could also be tested in combination with antibiotics.

\subsection{Antiparasital Activity}

The first study on gedunin's antimalarial activity was published in 1986 [94]. The antimalarial screening was performed against Plasmodium falciparum, the major human malaria parasite. Gedunin isolated from $A$. indica had an $\mathrm{IC}_{50}$ value of about $1 \mu \mathrm{M}$ after $48 \mathrm{~h}$ exposure $(0.3 \mu \mathrm{M}$ after $96 \mathrm{~h})$, equivalent to quinine. Gedunin presented an $\mathrm{IC}_{50}$ of $0.72 \mu \mathrm{g} / \mathrm{mL}$ in an in vitro assay against chloroquine resistant K1 strain of $P$. falciparum, but in an in vivo assay neither oral nor subcutaneous administration of this compound to mice infected with $P$. berghei, in a 4-day test at the dose of $90 \mathrm{mg} / \mathrm{kg} / \mathrm{day}$, resulted in inhibition of parasitemia [95]. Against two clones of P. falciparum, one sensitive to chloroquine (D6) and one chloroquine-resistant (W2), gedunin (isolated from C. odorata wood) presented an $\mathrm{IC}_{50}$ of 39 and $20 \mathrm{ng} / \mathrm{mL}$, respectively, having better activity against the resistant clone than chloroquine or quinine [22]. Gedunin isolated from bark of Khaya grandifoliola C. DC. proved to be effective against $P$. falciparum (W2/Indochina clone), with an $\mathrm{IC}_{50}$ of $1.25 \mu \mathrm{g} / \mathrm{mL}$, and also to some P. falciparum clinical isolates from symptomatic Cameroonian patients, with $\mathrm{IC}_{50}$ values ranging from 3.36 to $8.89 \mu \mathrm{g} / \mathrm{mL}$ [96]. Drug interaction between chloroquine and gedunin was also studied against P. falciparum (W2/Indochina clone) and gedunin exhibited an additive effect. Lee et al. [97] also tested gedunin against W2-strain using a $\left[{ }^{3} \mathrm{H}\right]$-hypoxanthine and 48-h culture assay in vitro; it presented antimalarial activity with $\mathrm{IC}_{50}$ values of 3.1 and $0.14 \mu \mathrm{M}$, respectively. Gedunin isolated from $A$. indica and $X$. granatum fruits showed in vitro antimalarial activity. In the first case, $\mathrm{IC}_{50}$ values of 1.66 and $1.31 \mu \mathrm{M}$ were observed for the P. falciparum D10 strain and W2 strain, respectively [98]. In the second case, the MIC of gedunin was determined for the P. falciparum 3D7 strain, at $10 \mu \mathrm{g} / \mathrm{mL}$ [99]. A limonoid-rich fraction from C. guianensis, containing gedunin, showed to be effective against W2 and $\mathrm{Dd}_{2}$ strains of P. falciparum [100]. The fraction inhibited growth of the $\mathrm{W} 2$ clone in $100 \%$ at concentration 
of $3.1 \mu \mathrm{g} / \mathrm{mL}$ ( 24 and $48 \mathrm{~h}$ ), and of the $\mathrm{Dd}_{2}$ clone in 56 and $82 \%$ (24 and $48 \mathrm{~h}$ ), with an $\mathrm{IC}_{50}$ value of $2.8 \mu \mathrm{g} / \mathrm{mL}$ and $0.4 \mu \mathrm{g} / \mathrm{mL}$, respectively.

In vitro antimalarial activity of gedunin has been widely studied and proved. However, in vivo, gedunin, micronized in water and administered to mice infected with P. berghei, proved not to be as effective [95]. This may be explained by the (1) poor solubility of gedunin, due to its lipophilicity; (2) first pass metabolism of gedunin by cytochrome P450 enzymes of the small intestine, which reduces plasma levels of drugs; and (3) hydrolysis of gedunin by the inactive and unstable metabolite, 7-deacetylgedunin [22]. In order to improve in vivo gedunin antimalarial activity, Omar et al. [23] used a combination of gedunin with dillapiol, a cytochrome P450 inhibitor, and also tested a structural modification of the compound. They concluded that gedunin was slightly active in parasite-infected mice due to poor pharmacokinetics. A synergistic treatment of $50 \mathrm{mg} / \mathrm{kg} /$ day gedunin with $25 \mathrm{mg}$ $\mathrm{kg} /$ day/dillapiol increased parasitemia clearance in mice to $75 \%$, with the addition of a stable methoxy group at the C-7 position and a $67.5 \%$ suppression rate.

Gedunin was revealed to be one of the most potent antimalarial limonoid. The conjugated enone system, the furan ring, and the acetoxy group at C-7 have been identified as critical for the antimalarial activity of gedunin, as well as the Michael acceptor in ring A [22]. More studies on the mechanisms of gedunin's antimalarial action, which remains elusive, could allow a better understanding of the structural requirements needed by an active molecule. Recently, an in silico study determined the binding affinities of limonoids, including gedunin, to the protein kinase 5 of P. falciparum (PfPK5) [101]. This protein kinase is described as necessary for the activation and maintenance of S-phase of the parasite, thus being recognized as one of the novel targets in falciparum species. All the molecules tested were able to bind to PfPK5 and gedunin was the second best of the test, with a binding-energy of $-5 \mathrm{kcal} / \mathrm{mol}$, right after 7-deacetoxy-7-oxogedunin and nimolicinol ( $-5.5 \mathrm{kcal} / \mathrm{mol}$, each). This was comparable to the result obtained for staurosporine, a known protein kinase inhibitor, at $-4.66 \mathrm{kcal} / \mathrm{mol}$. This result means that gedunin was able to fit into the binding cavity of the targeted protein and interact with the protein molecule via a hydrogen and pi-bond [101]. This study suggested that gedunin, along with other limonoids, could be a potential pfpk5 inhibitor, which could further be developed into antimalarial drugs.

Gedunin has also shown activity against human lymphatic filarial parasite, Brugia malayi. The compound was isolated from X. granatum fruits and tested in vitro and in vivo against the mentioned parasite [102]. Gedunin presented a good activity in vitro on both adult parasite and microfilaria, with $\mathrm{IC}_{50}$ values of 0.24 and $2.03 \mu \mathrm{g} / \mathrm{mL}$, respectively. In vivo, gedunin caused $80 \%$ mortality of adult worms in a 5 -day test at $100 \mathrm{mg} / \mathrm{kg} /$ day.

The activity of gedunin on Babesia and Theileria parasites was evaluated, for the first time, using an in vitro model by Azirwna et al. [103]. These authors used three strains of Babesia and one of Theileria, namely B. bovis (Texas strain), B. bigemina (Argentina strain), B. caballi (USDA strain), and T. equi (USDA strain). Gedunin inhibited the growth of Babesia parasites and the $\mathrm{IC}_{50}$ values were moderately low: $21.7,15.3$, and $22.1 \mu \mathrm{M}$ for B. bovis, B. bigemina, and B. caballi, respectively; and $33.2 \mu \mathrm{M}$ for T. equi. Morphological and degenerative changes were also observed in parasites treated with gedunin. An alternative method was later developed and optimized to microscopy screening of Babesia, a fluorescence-based method $[104,105]$. The newly developed method for drug evaluation against $B$. bovis was successfully achieved; the $\mathrm{IC}_{50}$ value obtained, $19 \mu \mathrm{M}$ [104], was comparable to the previously published microscopy-based value, $21.7 \mu \mathrm{M}$ [103], with no statistically significant $(p<0.05)$ difference between them. Initially, this method was not suitable for a large scale screening, since medium had to be replaced every day, but that was later overcome [105].

\subsection{Other Activities}

The effect of gedunin, isolated from powdered fruits of $X$. granatum, on $\mathrm{H}^{+} \mathrm{K}^{+}$-ATPase (proton pump) inhibitory activity in isolated gastric microsomes from rat stomach was studied by Lakshmi et al. [106]. Gedunin showed gastroprotective effects through the inhibition of proton pump activity 
with an $\mathrm{IC}_{50}$ of $56.86 \mu \mathrm{g} / \mathrm{mL}$. Thus, more studies could be performed as it can be considered a possible therapeutic agent in treating gastric ulcer.

According to Hullin-Matsuda et al. [107], gedunin inhibited more than half of de novo synthesis of sphingomyelin biosynthesis and ceramide transport protein (CERT)-mediated extraction of ceramide from endoplasmatic reticulum membrane. Ceramide has a central position in sphingolipid metabolism, which has been associated with cancer cell proliferation and Plasmodium development. Thus, gedunin's inhibition of sphingomyelin biosynthesis also represents a reasonable explanation for its anticancer and antimalaria properties. The fact that gedunin stimulates suicidal erythrocyte death or eryptosis, is also useful for anticancer and antimalaria therapy. This was proved by the treatment of human erythrocytes with gedunin, for $48 \mathrm{~h}$, which revealed that it significantly increased cytosolic $\mathrm{Ca}^{2+}$ activity and annexin-V-binding, and significantly decreased cell volume [108].

Known as an Hsp90 inhibitor, gedunin was used in a study related to the Duchenne and Becker muscular dystrophies [109]. The inhibition of Hsp90 and, consequently, the release of bound HSF1 for transcriptional activity, increased L54R GFP-dystrophin in cells treated with 10-80 $\mu \mathrm{M}$ gedunin. This suggests that pharmacologic activation of the heat shock system can facilitate stabilization of mutant dystrophin. The effectiveness of gedunin supports the idea of heat shock activators as a class of compounds with the potential to treat Duchenne muscular dystrophy patients with missense mutations.

A pool of six different tetranortriterpenoids containing gedunin, extracted from C. guianensis seed oil, was demonstrated to have anti-inflammatory activity, including articular inflammation, by inhibiting zymozan-induced knee joint inflammation [110]. More recently, Conte et al. [111] demonstrated that in vivo pre- and post-treatment with gedunin impaired several features of murine zymosan-induced arthritis in mice, including knee joint swelling, neutrophil influx, hyperalgesia, and production of inflammatory mediators. The compound directly damages neutrophil and macrophage activation by impairing calcium influx, chemotaxis, cell adhesion, and lipid body formation. Gedunin, isolated from flower oil of $C$. guianensis, presented anti-inflammatory activity by strongly affecting the production of $\mathrm{NO}$ in lipopolysaccharide (LPS)-activated mouse peritoneal macrophage $\left(\mathrm{IC}_{50}\right.$ value of $4.6 \mu \mathrm{M}$ ) [112] and had a protective effect against liver injury induced by D-galactosamine (D-GalN)/LPS in mice at a dose of $25 \mathrm{mg} / \mathrm{kg}$, p.o [113]. Ninomiya et al. [113] believe that the mechanism of action of gedunin may involve inhibition of LPS-induced macrophage activation and reduction of sensitivity of hepatocytes to tumor necrosis factor- $\alpha$ (TNF- $\alpha$ ), despite the fact that gedunin did not decrease the cytotoxicity caused by D-GalN. Recently, Morikawa et al. [114], found that gedunin, isolated from $C$. guianensis seed oil, significantly promoted collagen synthesis in normal human dermal fibroblasts to $133.3,134.7$, and $136.8 \%$ at 3,10 , and $30 \mu \mathrm{M}$, respectively, without cytotoxicity at the same concentrations [114].

\section{Toxicity}

Natural products from plants of Meliaceae family, especially from A. indica, have been safely consumed for several years [49]. However, it is important to know if this safety is extended to one of the pure compounds that can be extracted from those plants, gedunin. Its toxicity is not well characterized in either in vitro or in vivo models.

Gedunin was relatively non-toxic to guinea-pig ear epidermis (GPK) cells, with a median effective dose $\left(\mathrm{ED}_{50}\right)$ of $275.10 \mu \mathrm{g} / \mathrm{mL}$, and no toxicity was observed during its oral or subcutaneous administration at $90 \mathrm{mg} / \mathrm{kg} /$ day to mice, in a 4-day test [95]. Omar et al. [23] studied the pharmacokinetics of gedunin in order to determine its absorption, distribution and excretion in a mammalian model, using 12 male Sprague-Dawley rats (230-240 g) and administered radiolabeled gedunin at a dose of $50 \mathrm{mg} / \mathrm{kg}$ orally by gavage, providing a radioactive dose of approximately $6 \times 10^{6} \mathrm{dpm}$ per kg body weight. Blood was collected from the tail vein at 1, 2, 3, 6, 9, 12, 24, 48, 72, and $96 \mathrm{~h}$ and serum-analyzed for gedunin content. Poor absorption of the orally administered gedunin and rapid clearance of label from the blood were observed. The acute toxicity of gedunin was also investigated using five CD-1 male mice $(30 \pm 2 \mathrm{~g}$ ), each receiving a daily dose of $100 \mathrm{mg} / \mathrm{kg}$ of gedunin and $25 \mathrm{mg} / \mathrm{kg}$ of dillapiol for 
5 days. Weight changes were recorded every day for 14 days and, on the last day, blood was collected via cardiac puncture. Results showed no significant differences $(p<0.05)$ in total body or organ weight, gross anatomy or three liver enzyme levels relative to the control group, thus suggesting that the treatment had no acute mammalian toxicity.

Patwardhan et al. [30] revealed that adult-derived normal cells, Hs578Bst cells, and human mammary epithelial cells (HMEs) were remarkably resistant to gedunin treatment and that by comparing cell growth of cancer versus immortalized normal cell lines, gedunin selectively killed cancer cells. A similar result was obtained for pancreatic cells. Subramani et al. [36] showed that $25 \mu \mathrm{M}$ of gedunin were not able to significantly alter cell viability of normal pancreatic cells (hTERT-HPNE), and microscopic analysis also showed minimal or no reduction in cell number of hTERT-PNE treated. However, the same concentration of gedunin was able to induce approximately $50 \%$ cell death in three pancreatic cancer cell lines, suggesting that gedunin selectively kills pancreatic cancer cells and is nontoxic to normal ones.

The effects of gedunin on normal human cells were evaluated by WST-1 cell viability assay on human peripheral blood mononuclear cells [45]. The $\mathrm{IC}_{50}$ value obtained was $>100 \mu \mathrm{g} / \mathrm{mL}$ for all incubation periods tested $(24,48$, and $72 \mathrm{~h}$ ), which means gedunin is not cytotoxic to these cells. Nwokwu et al. [41] tested gedunin and gedunin-loaded liposomal nano-particles on normal human lung fibroblast (MRC-5) cells at different experimental timelines 24,48 , and $72 \mathrm{~h}$. The compound itself presented $\mathrm{IC}_{50}$ values of $>50 \mu \mathrm{g} / \mathrm{mL}$ at all times tested and gedunin liposomes presented $\mathrm{IC}_{50}$ values of $5.32,2.94$, and $4.90 \mu \mathrm{g} / \mathrm{mL}$ for 24,48 , and $72 \mathrm{~h}$, respectively. Nevertheless, gedunin liposomes were less toxic than the control drug used, paclitaxel $(p<0.05)$.

An in silico investigation evaluated gedunin's pharmacokinetics and toxicity [101]. The pharmacokinetic parameters and toxicity of selected biomolecules were predicted using admetSAR in different model and an online server, ABSYNTH, was used to predict Escherichia coli toxicity. The latter helps to predict the concentration of drug molecule required to inhibit the growth of the prokaryotic cell, and the value obtained for gedunin was $0.37 \mathrm{~g} / \mathrm{L}$. In terms of pharmacokinetic parameters, this study showed that gedunin had a positive result to cross blood-brain barrier and for human intestinal absorption, with a probability of 0.85 and 1, respectively. Regarding Caco-2 permeability, Ames toxicity, and carcinogenicity, gedunin presented negative results to all with a probability of $0.56,0.85$, and 0.92 , respectively. For acute oral toxicity gedunin was under class III with a probability of 0.37 . According to these pharmacokinetic results, gedunin is said to be suitable for human consumption. This study also predicted a median lethal dose $\left(\mathrm{LD}_{50}\right)$ of $3.07 \mathrm{~mol} / \mathrm{kg}$ and a $\mathrm{pIGC}_{50}$ of $1.27 \mu \mathrm{g} / \mathrm{L}$ for rat and Tetrahymena pyriformis, respectively.

\section{Materials and Methods}

A literature search using several online databases, such as PubMed, Science Direct, ISI Web of Knowledge, and Google scholar, was conducted up to September 2019. The principal search topics were related to gedunin and Meliaceae limonoids: its isolation, biological activities, toxicity, and chemistry. Secondary searches included articles cited in sources identified by the previous search.

\section{Conclusions and Future Perspectives}

From the studies presented and highlighted in this review, it is clear that gedunin, an important limonoid from the Meliaceae family, represents a natural compound with a great potential in terms of bioactivities, some of them of great value to prevent and treat a wide range of human diseases. The first studies on gedunin's biological activities were focused on antifungal, antibacterial, antiparasital and insecticidal, herbicidal, antifeedant, and nematicidal capacities. The discovery of gedunin as an Hsp 90 inhibitor represents a very important milestone for its study as a biological therapeutic agent. This finding opened the door to another therapeutic side of gedunin, especially its anticancer and neuroprotective aspects. 
There few studies about gedunin's antibacterial and antifungal activity, and it proved to be an effective agent. Newer studies against other pathogenic agents are required, for example, those on the WHO priority pathogens list. These studies should focus not only on the determination of gedunin's activity against microbiological agents, but also on its mechanism of action. Gedunin has also been proven to be a bioactive compound with respect to crop protection, and is effective against several pests. This represents an important future area of research that should focus on documenting the role of gedunin as an alternative to conventional chemical pesticides and insecticides, demonstrating its efficacy under field conditions, toxicity to mammalian, persistence in the environment, and biodegradability.

Gedunin has the potential to prevent or treat several human cancers, and its cytotoxic activity can be explained by multiple cellular and molecular mechanisms, including cell proliferation inhibition, apoptosis induction, and effect on tumor invasion and angiogenesis. A careful examination of the in vitro and in vivo anticancer studies presented here reveals that gedunin is effective in preventing or treating oral, stomach, colon, pancreatic, breast, ovarian, prostate, lung, brain, skin, leukemia, and stem cell cancers. However, further studies should be done in order to better understand the specific mechanism to treat each type of cancer. Another area of interest in this research field concerns the use of advanced technology such as liposomal drug delivery and nanoformulation to improve the efficacy of gedunin in cancer treatment, as well as the use of gedunin combined with other chemotherapeutic drugs. Other human diseases such as $\mathrm{AD}, \mathrm{PD}, \mathrm{DM}$, and malaria have found a new pathway of treatment through gedunin. In these cases, like for anticancer and also anti-inflammatory activity, further studies need to be conducted in order to better understand the specific mechanism leading to the treatment, and to also prove gedunin's safety for human consumption by performing pre-clinical and clinical trials.

In conclusion, gedunin shows significant promise for preventing and treating several human diseases, thus having a high commercial importance as well, but more studies need to be performed on its efficacy. Another important issue to note is that compounds like gedunin are difficult to produce at a quantity high enough from nature, and cannot be easily supported by chemical synthesis, which represents a great opportunity for commercial laboratories and for researchers.

Author Contributions: Conceptualization, T.M.B. and A.C.; writing-original draft preparation, T.M.B.; writingreview and editing, T.M.B., L.R., T.Y.C., R.F.O., C.P., A.I.O., J.M., and A.C. All authors have read and agreed to the published version of the manuscript.

Funding: This research was funded by Bio4Life4You.

Acknowledgments: The authors are grateful to Bio4Life4Youfor financial support and to World Neem Organization.

Conflicts of Interest: The authors declare no conflict of interest.

\section{Abbreviations}

$\begin{array}{ll}\text { A375-C5 } & \text { Human skin cancer cell line } \\ \text { A-549 } & \text { Human lung cancer cell line } \\ \text { A2870 } & \text { Human ovarian cancer cell line } \\ \text { AD } & \text { Alzheimer's disease } \\ \text { AKT } & \text { Serine/threonine kinase } \\ \text { AR } & \text { Androgen receptor } \\ \text { ARase } & \text { Aldose reductase } \\ \text { ATP } & \text { Adenosine triphosphate } \\ \text { ATPase } & \text { Adenosine triphosphatases } \\ \text { AZ521 } & \text { Human gastric cancer cell line } \\ \text { B16 } & \text { Mouse skin cancer cell line } \\ \text { Bax } & \text { B-cell lymphoma-2 protein associated X protein } \\ \text { Bcl2 } & \text { B-cell lymphoma 2 protein } \\ \text { C30 } & \text { Human ovarian cancer cell line } \\ \text { CaCo-2 } & \text { Human colon cancer }\end{array}$




\begin{tabular}{|c|c|}
\hline Cdc37 & Hsp 90 co-chaperone encoded by the CDC37 gene \\
\hline CDK1 & Cyclin dependent kinase 1 \\
\hline CHK1 & Checkpoint kinase 1 \\
\hline CP70 & Human ovarian cancer cell line \\
\hline CSCs & Cancer stem cells \\
\hline D-GalN & D-galactosamine \\
\hline $\mathrm{DM}$ & Diabetes mellitus \\
\hline DMBA & 7,12-Dimethylbenz[a]anthracene \\
\hline DNA & Dezoxiribonucleic acid \\
\hline $\mathrm{EC}_{50}$ & Half maximal effective concentration \\
\hline $\mathrm{ED}_{50}$ & Median effective dose \\
\hline EMT & Epithelial-to-mesenchymal transition \\
\hline FAK & Focal adhesion kinase \\
\hline $\mathrm{GI}_{50}$ & Median growth inhibition concentration \\
\hline GPK & Guinea-pig ear epidermis cells \\
\hline HBP & Hamster buccal pouch \\
\hline $\mathrm{HeLa}$ & Human cervical cancer cell line \\
\hline HL60 & Human promyelocytic leukemia cell line \\
\hline HIF1 $\alpha$ & Hypoxia inducible factor 1 alpha \\
\hline HME & Human mammary epithelial cell line \\
\hline HPA & Human pancreatic $\alpha$-amylase \\
\hline HPAC & Human pancreatic cancer cell line \\
\hline Hs578Bst & Human breast normal cell line \\
\hline HSF1 & Heat shock factor 1 \\
\hline Hsp & Heat shock protein \\
\hline Hs578T & Human breast cancer cell line \\
\hline hTERT-HPNE & Human pancreatic normal cell line \\
\hline $\mathrm{IC}_{50}$ & Half maximal inhibitory concentration \\
\hline ID8 & Mouse ovarian cancer cell line \\
\hline ID8TaxR & Raclitaxel-resistant mouse ovarian cancer cell lines \\
\hline IKK & Inhibitory kappa B kinase \\
\hline $\mathrm{LC}_{50}$ & Half maximal lethal concentration \\
\hline $\mathrm{LD}_{50}$ & Median lethal dose \\
\hline LNCaP & Human prostate cancer cell line \\
\hline LPS & Lipopolysaccharide \\
\hline MCF7 & Human breast cancer cell line \\
\hline MDA-MB-231 & Human breast cancer cell line \\
\hline MDA-MB-453 & Human breast cancer cell line \\
\hline MIAPaCa-2 & Human pancreatic cell line \\
\hline MIC & Minimum inhibitory concentration \\
\hline $\operatorname{miR}-21$ & MicroRNA-21 \\
\hline mRNA & Messenger ribonucleic acid \\
\hline MMP-9 & Matrix metallopeptidase 9 \\
\hline MRC-5 & Human lung normal cell line \\
\hline mTOR & Mammalian target of rapamycin \\
\hline NCI-H292 & Human lung cancer cell line \\
\hline NCI-H460 & Human lung cancer cell line \\
\hline NF-kB & Nuclear factor kappa B \\
\hline Nrf2 & Nuclear factor erythroid 2-related factor 2 \\
\hline $\mathrm{NO}$ & Nitric oxide \\
\hline NTERA-2 & Human pluripotent embryonal cancer cell line \\
\hline OVCAR4 & Human ovarian cancer cell line \\
\hline OVCAR8 & Human ovarian cancer cell line \\
\hline P338 & Menogaril-resistant mouse leukaemia cell line \\
\hline
\end{tabular}




$\begin{array}{ll}\text { PANC-1 } & \text { Human pancreatic cell line } \\ \text { PARP } & \text { Poly (ADP-ribose) polymerase } \\ \text { PfPK5 } & \text { Plasmodium falciparum protein kinase 5 } \\ \text { PHD2 } & \text { Prolyl hydroxylase domain protein 2 } \\ \text { PI3K } & \text { Phosphoinositide 3-kinases } \\ \text { PLK1 } & \text { Polo-like kinase 1 } \\ \text { PD } & \text { Parkinson's disease } \\ \text { ROCK-1 } & \text { Rho-associated protein kinase 1 } \\ \text { SCC131 } & \text { Human oral squamous cancer cell } \\ \text { SH-SY5Y } & \text { Human neuronal cells } \\ \text { SK-BR-3 } & \text { Human breast cancer cell line } \\ \text { SKOV3 } & \text { Human ovarian cancer cell line } \\ \text { STS } & \text { Standard target species } \\ \text { TLR } & \text { Toll-like receptor } \\ \text { U-251 MG } & \text { Human brain cancer cell line } \\ \text { WHO } & \text { World Health Organization }\end{array}$

\section{References}

1. Patra, J.K.; Das, G.; Lee, S.; Kang, S.S.; Shin, H.S. Selected commercial plants: A review of extraction and isolation of bioactive compounds and their pharmacological market value. Trends Food Sci. Technol. 2018, 82, 89-109. [CrossRef]

2. Paritala, V.; Chiruvella, K.K.; Thammineni, C.; Ghanta, R.G.; Mohammed, A. Phytochemicals and antimicrobial potentials of mahogany family. Rev. Bras. Farmacogn. 2015, 25, 61-83. [CrossRef]

3. Roy, A.; Saraf, S. Limonoids: Overview of significant bioactive triterpenes distributed in plants kingdom. Biol. Pharm. Bull. 2006, 29, 191-201. [CrossRef] [PubMed]

4. Tan, Q.-G.; Luo, X.-D. Meliaceous limonoids: Chemistry and biological activities. Chem. Rev. 2011, 111, 7437-7522. [CrossRef] [PubMed]

5. Uddin, S.J.; Nahar, L.; Shilpi, J.A.; Shoeb, M.; Borkowski, T.; Gibbons, S.; Middleton, M.; Byres, M.; Sarker, S.D. Gedunin, a limonoid from Xylocarpus granatum, inhibits the growth of $\mathrm{CaCo}-2$ colon cancer cell line in vitro. Phyther. Res. 2007, 21, 757-761. [CrossRef]

6. Carvalho, P.S.; Napolitano, H.B.; Camargo, A.J.; Silva, V.H.C.; Ellena, J.A.; Rocha, W.C.; Vieira, P.C. X-ray diffraction and theoretical investigation of the gedunin crystal structure. J. Mol. Struct. 2012, 1008, 83-87. [CrossRef]

7. Sahu, A.K.; Jain, V. The applied validated ultraviolet-visible spectrophotometric method and the kinetic model of the release of gedunin from a chitosan-coated liposome. J. Appl. Spectrosc. 2016, 83, 878-887. [CrossRef]

8. Koumaglo, K.; Akogo, Y.; Dotse, K.; Gbeassor, M.; Arnason, J.T. Évaluation de la teneur en gédunine dans différents organes d'Azadirachta indica A. Juss. Comptes Rendus Chim. 2004, 7, 1047-1050. [CrossRef]

9. Biswas, K.; Chattopadhyay, I.; Banerjee, R.K.; Bandyopadhyay, U. Biological activities and medicinal properties of neem (Azadirachta indica). Curr. Sci. 2002, 82, 1336-1345.

10. Hitotsuyanagi, Y.; Mitsui, K.; Fukaya, H.; Takeya, K. Fluorinated and rearranged gedunin derivatives. Phytochem. Lett. 2012, 5, 486-489. [CrossRef]

11. Nagini, S. Neem limonoids as anticancer agents: Modulation of cancer hallmarks and oncogenic signaling. In Enzymes. Natural Products and Cancer Signaling: Isoprenoids, Polyphenols and Flavonoids; Bathaie, S.Z., Tamanoi, F., Eds.; Academic Press: Cambridge, MA, USA, 2014; Volume 36, pp. 131-147. ISBN 9780128022153.

12. Narender, T.; Khaliq, T.; Shweta; Reddy, K.P.; Sharma, R.K. Occurrence, biosynthesis, biological activity and NMR spectroscopy of D and B, D ring seco-limonoids of Meliaceae family. Nat. Prod. Commun. 2007, 2, 203-221. [CrossRef]

13. Akhila, A.; Rani, K. Chemistry of the neem tree (Azadirachta indica A. Juss.). In Progress in the Chemistry of Organic Natural Products; Springer: Vienna, Austria, 1999; pp. 47-149.

14. Céspedes, C.L.; Calderón, J.S.; Lina, L.; Aranda, E. Growth inhibitory effects on fall armyworm Spodoptera frugiperda of some limonoids isolated from Cedrela spp. (Meliaceae). J. Agric. Food Chem. 2000, 48, 1903-1908. [CrossRef] [PubMed] 
15. Aarthy, T.; Mulani, F.A.; Pandreka, A.; Kumar, A.; Nandikol, S.S.; Haldar, S.; Thulasiram, H.V. Tracing the biosynthetic origin of limonoids and their functional groups through stable isotope labeling and inhibition in neem tree (Azadirachta indica) cell suspension. BMC Plant Biol. 2018, 18, 230-251. [CrossRef] [PubMed]

16. Akisanya, A.; Bevan, C.W.L.; Hirst, J.; Halsall, T.G.; Taylor, D.A.H. 758. West African timbers. Part III. Petroleum extracts from the genus Entandrophragma. J. Chem. Soc. 1960, 506-509. [CrossRef]

17. Akisanya, A.; Bevan, C.W.L.; Halsall, T.G.; Powell, J.W.; Taylor, D.A.H. 720. West African timbers. Part IV. Some reactions of gedunin. J. Chem. Soc. 1961, 3705-3708. [CrossRef]

18. Sutherland, S.A.; Sim, G.A.; Robertson, J.M. Structure of gedunin. Proc. Chem. Soc. Lond. 1962, $222-224$.

19. Powell, J.W. Nuclear magnetic resonance spectroscopy, the bandwidths of the singlets in gedunin and its simple derivatives. Chem. Commun. 1966, 422-423. [CrossRef]

20. Baldwin, M.A.; Loudon, A.G.; Maccoll, A.; Bevan, C.W.L. The mass spectra of meliacins and related compounds. Part I. Gedunin and related compounds. J. Chem. Soc. C Org. Chem. 1967, 1026-1034. [CrossRef]

21. Toscano, R.A.; Mata, R.; Calderon, J.; Segura, R. Gedunin, a D-seco limonoid. J. Chem. Crystallogr. 1996, 26, 707-711. [CrossRef]

22. MacKinnon, S.; Durst, T.; Arnason, J.T.; Angerhofer, C.; Pezzuto, J.; Sanchez-Vindas, P.E.; Poveda, L.J.; Gbeassor, M. Antimalarial activity of tropical Meliaceae extracts and gedunin derivatives. J. Nat. Prod. 1997, 60, 336-341. [CrossRef]

23. Omar, S.; Godard, K.; Ingham, A.; Hussain, H.; Wongpanich, V.; Pezzuto, J.; Durst, T.; Eklu, C.; Gbeassor, M.; Sanchez-Vindas, P.; et al. Antimalarial activities of gedunin and 7-methoxygedunin and synergistic activity with dillapiol. Ann. Appl. Biol. 2003, 143, 135-141. [CrossRef]

24. Brandt, G.E.L.; Schmidt, M.D.; Prisinzano, T.E.; Blagg, B.S.J. Gedunin, a novel hsp90 inhibitor: Semisynthesis of derivatives and preliminary structure-activity relationships. J. Med. Chem. 2008, 51, 6495-6502. [CrossRef] [PubMed]

25. Pinkerton, D.M.; Vanden Berg, T.J.; Bernhardt, P.V.; Williams, C.M. Gaining synthetic appreciation for the gedunin ABC ring system. Chem. A Eur. J. 2017, 23, 2282-2285. [CrossRef] [PubMed]

26. Pinkerton, D.M.; Bernhardt, P.V.; Savage, G.P.; Williams, C.M. Towards the total synthesis of gedunin: Construction of the fully elaborated ABC ring system. Asian J. Org. Chem. 2017, 6, 583-597. [CrossRef]

27. Pinkerton, D.M.; Chow, S.; Eisa, N.H.; Kainth, K.; Vanden Berg, T.J.; Burns, J.M.; Guddat, L.W.; Savage, G.P.; Chadli, A.; Williams, C.M. Synthesis of the seco-limonoid BCD ring system identifies a Hsp90 chaperon machinery (p23) inhibitor. Chem. A Eur. J. 2019, 25, 1451-1455. [CrossRef]

28. Kamath, S.G.; Chen, N.; Xiong, Y.; Wenham, R.; Apte, S.; Humphrey, M.; Cragun, J.; Lancaster, J.M. Gedunin, a novel natural substance, inhibits ovarian cancer cell proliferation. Int. J. Gynecol. Cancer 2009, 19, 1564-1569. [CrossRef]

29. Johnson, J.; Venugopal, A.; Kwatra, D.; Roby, K.; Godwin, A.; Anant, S. Gedunin, a novel HSP-90 inhibitor, synergizes with cisplatin and paclitaxel to inhibit growth of chemoresistant ovarian cancer cell lines. In Proceedings of the 105th Annual Meeting of the American Association for Cancer Research, San Diego, CA, USA, 5-9 April 2014; American Association for Cancer Research: Philadelphia, PA, USA, 2014.

30. Patwardhan, C.A.; Fauq, A.; Peterson, L.B.; Miller, C.; Blagg, B.S.J.; Chadli, A. Gedunin inactivates the co-chaperone p23 protein causing cancer cell death by apoptosis. J. Biol. Chem. 2013, 288, 7313-7325. [CrossRef]

31. Cazal, C.M.; Choosang, K.; Severino, V.G.P.; Soares, M.S.; Sarria, A.L.F.; Fernandes, J.B.; Silva, M.F.G.F.; Vieira, P.C.; Pakkong, P.; Almerida, G.M.; et al. Evaluation of effect of triterpenes and limonoids on cell growth, cell cycle and apoptosis in human tumor cell lines. Anti-Cancer Agents Med. Chem. 2010, 10, 769-776. [CrossRef]

32. Manosroi, A.; Kitdamrongtham, W.; Ishii, K.; Shinozaki, T.; Tachi, Y.; Takagi, M.; Ebina, K.; Zhang, J.; Manosroi, J.; Akihisa, R.; et al. Limonoids from Azadirachta indica var. siamensis extracts and their cytotoxic and melanogenesis-inhibitory activities. Chem. Biodivers. 2014, 11, 505-531. [CrossRef]

33. Kikuchi, T.; Ishii, K.; Noto, T.; Takahashi, A.; Tabata, K.; Suzuki, T.; Akihisa, T. Cytotoxic and apoptosis-inducing activities of limonoids from the seeds of Azadirachta indica (Neem). J. Nat. Prod. 2011, 74, 866-870. [CrossRef]

34. Kishore, T.K.K.; Ganugula, R.; Gade, D.R.; Reddy, G.B.; Nagini, S. Gedunin abrogates aldose reductase, $\mathrm{PI} 3 \mathrm{~K} / \mathrm{Akt} / \mathrm{mToR}$, and NF- $\mathrm{BB}$ signaling pathways to inhibit angiogenesis in a hamster model of oral carcinogenesis. Tumor Biol. 2016, 37, 2083-2093. [CrossRef] [PubMed] 
35. Tanagala, K.K.K.; Baba, A.B.; Kowshik, J.; Reddy, G.B.; Nagini, S. Gedunin, a neem limonoid in combination with epalrestat inhibits cancer hallmarks by attenuating aldose reductase-driven oncogenic signaling in SCC131 oral cancer cells. Anticancer. Agents Med. Chem. 2018, 18, 2042-2052. [CrossRef] [PubMed]

36. Subramani, R.; Gonzalez, E.; Nandy, S.B.; Arumugam, A.; Camacho, F.; Medel, J.; Alabi, D.; Lakshmanaswamy, R. Gedunin inhibits pancreatic cancer by altering sonic hedgehog signaling pathway. Oncotarget 2017, 8 , 10891-10904. [CrossRef] [PubMed]

37. Lamb, J.; Crawford, E.D.; Peck, D.; Modell, J.W.; Blat, I.C.; Wrobel, M.J.; Lerner, J.; Brunet, J.P.; Subramanian, A.; Ross, K.N.; et al. The connectivity map: Using gene-expression signatures to connect small molecules, genes, and disease. Science 2006, 313, 1929-1935. [CrossRef]

38. Hieronymus, H.; Lamb, J.; Ross, K.N.; Peng, X.P.; Clement, C.; Rodina, A.; Nieto, M.; Du, J.; Stegmaier, K.; Raj, S.M.; et al. Gene expression signature-based chemical genomic prediction identifies a novel class of HSP90 pathway modulators. Cancer Cell 2006, 10, 321-330. [CrossRef]

39. Boopalan, T.; Chaudhary, A.; Murali, S.; Arumugam, A.; Lopez, R.; Nandy, S.; Gutierrez, C.; Parada, J.; Agullo, P.; Lakshmanaswamy, R. Anticancer effect of gedunin against pancreatic cancer cell lines. In Proceedings of the 104th AACR Annual Meeting 2013, Washington, DC, USA, 6-10 April 2013; Volume 73.

40. Hasan, A.; Haque, E.; Kamil, M.; Fatima, J.; Irfan, S.; Khatoon, A.; Yusuf, M.A.; Mir, S.S. PI3K/AKT Pathway is inhibited in NSCLC cell line A549 by downregulation of EGFR via an HSP-90 inhibitor Gedunin. Cancer Med. 2018, 7, 25-26. [CrossRef]

41. Nwokwu, C.D.U.; Samarakoon, S.R.; Karunaratne, D.N.; Katuvawila, N.P.; Pamunuwa, G.K.; Ediriweera, M.K.; Tennekoon, K.H. Induction of apoptosis in response to improved gedunin by liposomal nano-encapsulation in human non-small-cell lung cancer (NCI-H292) cell line. Trop. J. Pharm. Res. 2017, 16, 2079-2087. [CrossRef]

42. Li, H.; Wu, J.G.; Zhang, H.W.; Wang, W.; Zhang, Y.X.; Zhang, J.N. Inhibition of proliferation, invasion and migration in U-251 MG glioblastoma cell line by gedunin. Int. J. Pharmacol. 2018, 14, 522-527. [CrossRef]

43. Sakamoto, A.; Tanaka, Y.; Inoue, T.; Kikuchi, T.; Kajimoto, T.; Muraoka, O.; Yamada, T.; Tanaka, R. Andirolides Q-V from the flower of andiroba (Carapa guianensis, Meliaceae). Fitoterapia 2013, 90, 20-29. [CrossRef]

44. Akihisa, T.; Noto, T.; Takahashi, A.; Fujita, Y.; Banno, N.; Tokuda, H.; Koike, K.; Suzuki, T.; Yasukawa, K.; Kimura, Y. Melanogenesis inhibitory, anti-inflammatory, and chemopreventive effects of limonoids from the seeds of Azadirachta indicia A. Juss. (Neem). J. Oleo Sci. 2009, 594, 581-594. [CrossRef]

45. Tharmarajah, L.; Samarakoon, S.R.; Ediriweera, M.K.; Piyathilaka, P.; Tennekoon, K.H.; Senathilake, K.S.; Rajagopalan, U.; Galhena, P.B.; Thabrew, I. In vitro anticancer effect of gedunin on human teratocarcinomal (NTERA-2) cancer stem-like cells. Biomed Res. Int. 2017, 2017, 2413197. [CrossRef] [PubMed]

46. Piaz, F.; Terracciano, S.; De Tommasi, N.; Braca, A. Hsp90 activity modulation by plant secondary metabolites. Planta Med. 2015, 81, 1223-1239. [CrossRef] [PubMed]

47. Dutta Gupta, S.; Bommaka, M.K.; Banerjee, A. Inhibiting protein-protein interactions of Hsp90 as a novel approach for targeting cancer. Eur. J. Med. Chem. 2019, 178, 48-63. [CrossRef] [PubMed]

48. Matts, R.L.; Brandt, G.E.L.; Lu, Y.; Dixit, A.; Mollapour, M.; Wang, S.; Donnelly, A.C.; Neckers, L.; Verkhivker, G.; Blagg, B.S.J. A systematic protocol for the characterization of Hsp90 modulators. Bioorg. Med. Chem. 2011, 19, 684-692. [CrossRef]

49. Moga, M.A.; Bălan, A.; Anastasiu, C.V.; Dimienescu, O.G.; Neculoiu, C.D.; Gavris, C. An overview on the anticancer activity of Azadirachta indica (Neem) in gynecological cancers. Int. J. Mol. Sci. 2018, 19, 3898. [CrossRef]

50. Wen, P.Y.; Kesari, S. Malignant gliomas in adults. N. Engl. J. Med. 2008, 359, 492-507. [CrossRef]

51. Delude, C. Tumorigenesis: Testing ground for cancer stem. Nature 2011, 480, S43-S45. [CrossRef]

52. Mayan, K.; Samarakoon, S.; Tennekoon, K.; Siriwardana, A.; Valverde, J. Evaluation of selected natural compounds for cancer stem cells targeted anti-cancer activity: A molecular docking study. Eur. J. Med. Plants 2016, 15, 1-21. [CrossRef]

53. Seidl, S.E.; Potashkin, J.A. The promise of neuroprotective agents in Parkinson's disease. Front. Neurol. 2011, 21, 1-19. [CrossRef]

54. Rajagopalan, S.; Rane, A.; Chinta, S.J.; Andersen, J.K. Regulation of ATP13A2 via PHD2-HIF1 signaling is critical for cellular iron homeostasis: Implications for Parkinson's disease. J. Neurosci. 2016, 36, 1086-1095. [CrossRef] 
55. Rane, A.; Rajagopalan, S.; Ahuja, M.; Thomas, B.; Chinta, S.J.; Andersen, J.K. Hsp90 Co-chaperone p23 contributes to dopaminergic mitochondrial stress via stabilization of PHD2: Implications for Parkinson's disease. Neurotoxicology 2018, 65, 166-173. [CrossRef] [PubMed]

56. Tom, S.; Rane, A.; Katewa, A.S.; Chamoli, M.; Matsumoto, R.R.; Andersen, J.K.; Chinta, S.J. Gedunin inhibits oligomeric A $\beta 1-42$-induced microglia activation via modulation of Nrf2-NF-кB signaling. Mol. Neurobiol. 2019, 1-12. [CrossRef] [PubMed]

57. Borges, P.V.; Moret, K.H.; Maya-Monteiro, C.M.; Souza-Silva, F.; Alves, C.R.; Batista, P.R.; Caffarena, E.R.; Pacheco, P.; Henriques, M.G.; Penido, C. Gedunin binds to myeloid differentiation protein 2 and impairs lipopolysaccharide-induced toll-like receptor 4 signaling in macrophages. Mol. Pharmacol. 2015, 88, 949-961. [CrossRef] [PubMed]

58. Borges, P.V.; Moret, K.H.; Raghavendra, N.M.; Maramaldo Costa, T.E.; Monteiro, A.P.; Carneiro, A.B.; Pacheco, P.; Temerozo, J.R.; Bou-Habib, D.C.; das Graças Henriques, M.; et al. Protective effect of gedunin on TLR-mediated inflammation by modulation of inflammasome activation and cytokine production: Evidence of a multitarget compound. Pharmacol. Res. 2017, 115, 65-77. [CrossRef]

59. Smirnova, N.A.; Haskew-Layton, R.E.; Basso, M.; Hushpulian, D.M.; Payappilly, J.B.; Speer, R.E.; Ahn, Y.H.; Rakhman, I.; Cole, P.A.; Pinto, J.T.; et al. Development of Neh2-luciferase reporter and its application for high throughput screening and real-time monitoring of Nrf2 activators. Chem. Biol. 2011, 18, 752-765. [CrossRef]

60. Bastaki, S. Diabetes mellitus and its treatment. Int. J. Diabetes Metab. 2005, 13, 111-134. [CrossRef]

61. Tarling, C.A.; Woods, K.; Zhang, R.; Brastianos, H.C.; Brayer, G.D.; Andersen, R.J.; Withers, S.G. The search for novel human pancreatic $\alpha$-amylase inhibitors: High-throughput screening of terrestrial and marine natural product extracts. ChemBioChem 2008, 9, 433-438. [CrossRef]

62. Ponnusamy, S.; Haldar, S.; Mulani, F.; Zinjarde, S.; Thulasiram, H.; RaviKumar, A. Gedunin and azadiradione: Human pancreatic $\alpha$-amylase inhibiting limonoids from neem (Azadirachta indica) as anti-diabetic agents. PLoS ONE 2015, 10, 1-19. [CrossRef]

63. Ferraris, F.K.; Moret, K.H.; Figueiredo, A.B.C.; Penido, C.; Henriques, M.G.M.O. Gedunin, a natural tetranortriterpenoid, modulates $\mathrm{T}$ lymphocyte responses and ameliorates allergic inflammation. Int. Immunopharmacol. 2012, 14, 82-93. [CrossRef]

64. Penido, C.; Costa, K.A.; Pennaforte, R.J.; Costa, M.F.S.; Pereira, J.F.G.; Siani, A.C.; Henriques, M.G.M.O. Anti-allergic effects of natural tetranortriterpenoids isolated from Carapa guianensis Aublet on allergen-induced vascular permeability and hyperalgesia. Inflamm. Res. 2005, 54, 295-303. [CrossRef]

65. Penido, C.; Costa, K.A.; Costa, M.F.S.; Pereira, J.F.G.; Siani, A.C.; Henriques, M.G.M.O. Inhibition of allergen-induced eosinophil recruitment by natural tetranortriterpenoids is mediated by the suppression of IL-5, CCL11/eotaxin and NFאB activation. Int. Immunopharmacol. 2006, 6, 109-121. [CrossRef] [PubMed]

66. Senthil Nathan, S.; Kalaivani, K.; Sehoon, K.; Murugan, K. The toxicity and behavioural effects of neem limonoids on Cnaphalocrocis medinalis (Guenée), the rice leaffolder. Chemosphere 2006, 62, 1381-1387. [CrossRef] [PubMed]

67. Kubo, I.; Klocke, J. Insect ecdysis inhibitors. In Natural Resistance of Plants to Pests; American Chemical Society: Washington, DC, USA, 1986; Volume 296, pp. 206-219. [CrossRef]

68. Calderón, J.S.; Céspedes, C.L.; Rosas, R.; Ómez-Garibay, F.G.; Salazar, J.R.; Linab, L.; Randab, D.A.; Kuboc, I. Acetylcholinesterase and insect growth inhibitory activities of gutierrezia microcephala on fall army worm Spodoptera frugiperda J. E. Smith. Zeitschrift für Naturforschung C 2001, 56, 382-394. [CrossRef] [PubMed]

69. Torres, P.; Avila, J.G.; Romo de Vivar, A.; García, A.M.; Marín, J.C.; Aranda, E.; Céspedes, C.L. Antioxidant and insect growth regulatory activities of stilbenes and extracts from Yucca periculosa. Phytochemistry 2003, 64, 463-473. [CrossRef]

70. Céspedes, C.L.; Torres, P.; Marín, J.C.; Arciniegas, A.; Romo De Vivar, A.; Pérez-Castorena, A.L.; Aranda, E. Insect growth inhibition by tocotrienols and hydroquinones from Roldana barba-johannis. Phytochemistry 2004, 65, 1963-1975. [CrossRef] [PubMed]

71. Céspedes, C.L.; Salazar, J.R.; Martínez, M.; Aranda, E. Insect growth regulatory effects of some extracts and sterols from Myrtillocactus geometrizans (Cactaceae) against Spodoptera frugiperda and Tenebrio molitor. Phytochemistry 2005, 66, 2481-2493. [CrossRef]

72. Nathan, S.S.; Kalaivani, K.; Murugan, K.; Gene Chung, P. Efficacy of neem limonoids on Cnaphalocrocis medinalis (Guenée) (Lepidoptera: Pyralidae) the rice leaffolder. Crop Prot. 2005, 24, 760-763. [CrossRef] 
73. Nathan, S.S.; Kalaivani, K.; Murugan, K.; Chung, P.G. The toxicity and physiological effect of neem limonoids on Cnaphalocrocis medinalis (Guenée) the rice leaffolder. Pestic. Biochem. Physiol. 2005, 81, 113-122. [CrossRef]

74. Nathan, S.S.; Kalaivani, K.; Chung, P.G.; Murugan, K. Effect of neem limonoids on lactate dehydrogenase (LDH) of the rice leaffolder, Cnaphalocrocis medinalis (Guenée) (Insecta: Lepidoptera: Pyralidae). Chemosphere 2005, 62, 1388-1393. [CrossRef]

75. Siddiqui, B.S.; Rasheed, M.; Faizi, S.; Firdous; Ali, S.T.; Tariq, R.M.; Naqvi, S.N.-H. Transformation of azadiradione to nimbocinol and $17 \beta$-hydroxynimbocinol, and structure pesticidal-activity relationship of triterpenoids isolated from Azadirachta indica A. Juss. (Neem). Helv. Chim. Acta 2003, 86, 3342-3353. [CrossRef]

76. Nathan, S.S.; Kalaivani, K.; Murugan, K. Effects of neem limonoids on the malaria vector Anopheles stephensi Liston (Diptera: Culicidae). Acta Trop. 2005, 96, 47-55. [CrossRef] [PubMed]

77. Arnason, J.T.; Philogène, B.J.R.; Donskov, N.; Kubo, I. Limonoids from the Meliaceae and Rutaceae reduce feeding, growth and development of Ostrinia nubilalis. Entomol. Exp. Appl. 1987, 43, 221-226. [CrossRef]

78. Ewete, F.K.; Arnason, J.T.; Durst, T.; Mackinnon, S. Toxicity of gedunin, piperine and crude extracts of their natural products on growth and development of Ostrinia nubilalis Hübner (Lepidoptera: Pyralidae). Discov. Innov. 2000, 12, 67-72. [CrossRef]

79. Ishida, M.; Serit, M.; Nakata, K.; Raj Juneja, L.; Kim, M.; Takahashi, S. Several antifeedants from neem oil, Azadirachta indica A. Juss., against Reticulitermes speratus Kolbe (Isoptera: Rhinotermitidae). Biosci. Biotechnol. Biochem. 1992, 56, 1835-1838. [CrossRef]

80. Serit, M.; Ishida, M.; Nakata, K.; Kim, M.; Takahashi, S. Antifeeding potency of neem (Azadirachta indica) extractives and limonoids against termite (Reticulitermes speratus). J. Pestic. Sci. 1992, 17, 267-273. [CrossRef]

81. Murugan, K.; Jeyabalan, D.; Kumar, N.S.; Babu, R.; Sivaramakrishnan, S.; Nathan, S.S. Antifeedant and growth-inhibitory properties of neem limonoids against the cotton bollworm, Helicoverpa armigera (Hübner). Int. J. Trop. Insect Sci. 1998, 18, 157-162. [CrossRef]

82. Koul, O.; Multani, J.S.; Singh, G.; Daniewski, W.M.; Berlozecki, S. 6 $\beta$-hydroxygedunin from Azadirachta indica. Its potentiation effects with some non-azadirachtin limonoids in neem against lepidopteran larvae. J. Agric. Food Chem. 2003, 51, 2937-2942. [CrossRef]

83. Omar, S.; Marcotte, M.; Fields, P.; Sanchez, P.E.; Poveda, L.; Mata, R.; Jimenez, A.; Durst, T.; Zhang, J.; MacKinnon, S.; et al. Antifeedant activities of terpenoids isolated from tropical Rutales. J. Stored Prod. Res. 2007, 43, 92-96. [CrossRef]

84. Gurulingappa, H.; Tare, V.; Pawar, P.; Tungikar, V.; Jorapur, Y.R.; Madhavi, S.; Bhat, S.V. Susceptibility of Aedes aegypti and Culex quinquefasciatus larvae to gedunin-related limonoids. Chem. Biodivers. 2009, 6, 897-902. [CrossRef]

85. Park, E.S.; Bae, I.K.; Jeon, H.J.; Lee, S.-E. Limonoid derivatives and its pesticidal activities. Entomol. Res. 2014, 44, 158-162. [CrossRef]

86. Matos, A.P.; Leite, A.C.; Batista-Pereira, L.G.; Vieira, P.C.; Fernandes, J.B.; Silva, M.F.G.F. Effects of limonoids from Cipadessa fruticosa on fall armyworm. Zeitschrift für Naturforschung C 2009, 64, 441-446. [CrossRef] [PubMed]

87. Muñoz, E.; Escalona, D.; Salazar, J.R.; Alarcon, J.; Céspedes, C.L. Insect growth regulatory effects by diterpenes from Calceolaria talcana Grau \& Ehrhart (Calceolariaceae: Scrophulariaceae) against Spodoptera frugiperda and Drosophila melanogaster. Ind. Crops Prod. 2013, 45, 283-292. [CrossRef]

88. Quiroz, S.; Cespedes, C.L.; Alderete, J.B.; Alarcon, J. Ceanothane and oleanane-type triterpenes from Talguenea quinquenervia have insecticidal activity against Cydia pomonella, Tenebrio molitor and Drosophila melanogaster. Ind. Crops Prod. 2015, 74, 759-766. [CrossRef]

89. Cespedes, C.L.; Lina-Garcia, L.; Kubo, I.; Salazar, J.R.; Ariza-Castolo, A.; Alarcon, J.; Aqueveque, P.; Werner, E.; Seigler, D.S. Calceolaria integrifolia s.l. complex, reduces feeding and growth of Acanthoscelides obtectus, and Epilachna varivestis. A new source of bioactive compounds against dry bean pests. Ind. Crops Prod. 2016, 89, 257-267. [CrossRef]

90. Kraus, W.; K6ll-Weber, M.; Maile, R.; Wunder, T.; Vogler, B. Biologically active constituents of tropical and subtropical plants. Pure Appl. Chem. 1994, 66, 2347-2352. [CrossRef] 
91. Nebo, L.; Varela, R.M.; Molinillo, J.M.G.; Severino, V.G.P.; Sarria, A.L.F.; Cazal, C.M.; Fernandes, M.F.D.G.; Fernandes, J.B.; Macías, F.A. Phytotoxicity of triterpenes and limonoids from the Rutaceae and Meliaceae. $5 \alpha, 6 \beta, 8 \alpha, 12 \alpha$-tetrahydro-28-norisotoonafolin-A potent phytotoxin from Toona ciliata. Nat. Prod. Commun. 2015, 10, 17-20. [CrossRef]

92. Rao, B.S.; Nazma Rao, J.M. Antifungal activity of gedunin. Curr. Sci. 1977, 46, 714-716.

93. Ribeiro, A.B.; Abdelnur, P.V.; Garcia, C.F.; Belini, A.; Severino, V.G.; da Silva, M.F.; Fernandes, J.B.; Vieira, P.C.; de Carvalho, S.A.; de Souza, A.A.; et al. Chemical characterization of Citrus sinensis grafted on C. limonia and the effect of some isolated compounds on the growth of Xylella fastidiosa. J. Agric. Food Chem. 2008, 56, 7815-7822. [CrossRef]

94. Khalid, S.A.; Farouk, A.; Geary, T.G.; Jensen, J.B. Potential antimalarial candidates from African plants: An in vitro approach using Plasmodium falciparum. J. Ethnopharmacol. 1986, 15, 201-209. [CrossRef]

95. Bray, D.H.; Warhurst, D.C.; Connolly, J.D.; O’Neill, M.J.; Phillipson, J.D. Plants as sources of antimalarial drugs. Part 7. Activity of some species of Meliaceae plants and their constituent limonoids. Phyther. Res. 1990, 4, 29-35. [CrossRef]

96. Bickii, J.; Njifutie, N.; Ayafor Foyere, J.; Basco, L.K.; Ringwald, P. In vitro antimalarial activity of limonoids from Khaya grandifoliola C.D.C. (Meliaceae). J. Ethnopharmacol. 2000, 69, 27-33. [CrossRef]

97. Lee, S.-E.; Kim, M.-R.; Kim, J.-H.; Takeoka, G.R.; Kim, T.-W.; Park, B.-S. Antimalarial activity of anthothecol derived from Khaya anthotheca (Meliaceae). Phytomedicine 2008, 15, 533-535. [CrossRef] [PubMed]

98. Chianese, G.; Yerbanga, S.R.; Lucantoni, L.; Habluetzel, A.; Basilico, N.; Taramelli, D.; Fattorusso, E.; Taglialatela-Scafati, O. Antiplasmodial triterpenoids from the fruits of neem, Azadirachta indica. J. Nat. Prod. 2010, 73, 1448-1452. [CrossRef] [PubMed]

99. Lakshmi, V.; Srivastava, S.; Mishra, S.K.; Srivastava, M.N.; Srivastava, K.; Puri, S.K. Antimalarial activity in Xylocarpus granatum (Koen). Nat. Prod. Res. 2012, 26, 1012-1015. [CrossRef] [PubMed]

100. Miranda Júnior, R.N.C.; Dolabela, M.F.; da Silva, M.N.; Póvoa, M.M.; Maia, J.G.S. Antiplasmodial activity of the andiroba (Carapa guianensis Aubl., Meliaceae) oil and its limonoid-rich fraction. J. Ethnopharmacol. 2012, 142, 679-683. [CrossRef] [PubMed]

101. Khanal, P.; Mandar, B.K.; Magadum, P.; Patil, B.M.; Hullatti, K.K. In silico docking study of limonoids from Azadirachta indica with pfpk5: A novel target for Plasmodium falciparum. Indian J. Pharm. Sci. 2019, 81, 326-332. [CrossRef]

102. Misra, S.; Verma, M.; Mishra, S.K.; Srivastava, S.; Lakshmi, V.; Misra-Bhattacharya, S. Gedunin and photogedunin of Xylocarpus granatum possess antifilarial activity against human lymphatic filarial parasite Brugia malayi in experimental rodent host. Parasitol. Res. 2011, 109, 1351-1360. [CrossRef]

103. Azirwan, G.; Thillaiampalam, S.; Muncharee, T.; Yokoyama, N.; Igarashi, I. In vitro inhibitory effect of gedunin on Babesia and Theileria parasites. J. Protozool. Res. 2013, 23, 1-6. [CrossRef]

104. Guswanto, A.; Sivakumar, T.; Rizk, M.A.; Elsayed, S.A.E.; Youssef, M.A.; El Shirbini Elsaid, E.; Yokoyama, N.; Igarashia, I. Evaluation of a fluorescence-based method for antibabesial drug screening. Antimicrob. Agents Chemother. 2014, 58, 4713-4717. [CrossRef]

105. Rizk, M.A.; El-Sayed, S.A.E.S.; Terkawi, M.A.; Youssef, M.A.; El Said, E.S.E.S.; Elsayed, G.; El-Khodery, S.; El-Ashker, M.; Elsify, A.; Omar, M.; et al. Optimization of a fluorescence-based assay for large-scale drug screening against Babesia and Theileria parasites. PLoS ONE 2015, 10, 1-15. [CrossRef]

106. Lakshmi, V.; Singh, N.; Shrivastva, S.; Mishra, S.K.; Dharmani, P.; Mishra, V.; Palit, G. Gedunin and photogedunin of Xylocarpus granatum show significant anti-secretory effects and protect the gastric mucosa of peptic ulcer in rats. Phytomedicine 2010, 17, 569-574. [CrossRef] [PubMed]

107. Hullin-Matsuda, F.; Tomishige, N.; Sakai, S.; Ishitsuka, R.; Ishii, K.; Makino, A.; Greimel, P.; Abe, M.; Laviad, E.L.; Lagarde, M.; et al. Limonoid compounds inhibit sphingomyelin biosynthesis by preventing CERT protein-dependent extraction of ceramides from the endoplasmic reticulum. J. Biol. Chem. 2012, 287, 24397-24411. [CrossRef] [PubMed]

108. Lupescu, A.; Bissinger, R.; Warsi, J.; Jilani, K.; Lang, F. Stimulation of erythrocyte cell membrane scrambling by gedunin. Cell. Physiol. Biochem. 2014, 33, 1838-1848. [CrossRef] [PubMed]

109. Talsness, D.M.; Belanto, J.J.; Ervasti, J.M. Disease-proportional proteasomal degradation of missense dystrophins. Proc. Natl. Acad. Sci. USA 2015, 112, 12414-12419. [CrossRef] [PubMed] 
110. Penido, C.; Conte, F.P.; Chagas, S.; Rodrigues, C.A.B.; Pereira, J.F.G.; Henriques, M.G.M.O. Antiinflammatory effects of natural tetranortriterpenoids isolated from Carapa guianensis Aublet on zymosan-induced arthritis in mice. Inflamm. Res. 2006, 55, 457-464. [CrossRef] [PubMed]

111. Conte, F.; Ferraris, F.; Costa, T.; Pacheco, P.; Seito, L.; Verri, W.; Cunha, F.; Penido, C.; Henriques, M.; Conte, F.P.; et al. Effect of gedunin on acute articular inflammation and hypernociception in mice. Molecules 2015, 20, 2636-2657. [CrossRef]

112. Sakamoto, A.; Tanaka, Y.; Yamada, T.; Kikuchi, T.; Muraoka, O.; Ninomiya, K.; Morikawa, T.; Tanaka, R. Andirolides W-Y from the flower oil of andiroba (Carapa guianensis, Meliaceae). Fitoterapia 2015, 100, 81-87. [CrossRef]

113. Ninomiya, K.; Miyazawa, S.; Ozeki, K.; Matsuo, N.; Muraoka, O.; Kikuchi, T.; Yamada, T.; Tanaka, R.; Morikawa, T. Hepatoprotective limonoids from andiroba (Carapa guianensis). Int. J. Mol. Sci. 2016, 17, 591. [CrossRef]

114. Morikawa, T.; Nagatomo, A.; Kitazawa, K.; Muraoka, O.; Kikuchi, T.; Yamada, T.; Tanaka, R.; Ninomiya, K. Collagen synthesis-promoting effects of andiroba oil and its limonoid constituents in normal human dermal fibroblasts. J. Oleo Sci. 2018, 67, 1271-1277. [CrossRef]

(C) 2020 by the authors. Licensee MDPI, Basel, Switzerland. This article is an open access article distributed under the terms and conditions of the Creative Commons Attribution (CC BY) license (http://creativecommons.org/licenses/by/4.0/). 